\title{
BRUNO KAROLSKI
}

\section{Efeito da inativação do elemento Tnt1 na regeneração de plantas de fumo}

São Paulo

2007 


\section{BRUNO KAROLSKI}

\section{Efeito da inativação do elemento Tnt1 na regeneração de plantas de fumo.}

Dissertação apresentada ao Instituto de Biociências da Universidade de São Paulo, para a obtenção de Título de Mestre em Ciências, na Área de Botânica.

Orientadora: $\operatorname{Prof}^{\mathrm{a}} \operatorname{Dr}^{\mathrm{a}}$ Marie Anne Van Sluys 
Karolski, Bruno

Efeito da inativação do elemento Tnt1 na regeneração de plantas de fumo.

Número de páginas: 81

Dissertação (Mestrado) - Instituto de Biociências da Universidade de São Paulo. Departamento de Botânica.

1. Tnt1 2. RNAi

Universidade de São Paulo. Instituto de Biociências. Departamento de Botânica.

Comissão Julgadora:

Prof(a). Dr(a).

Prof(a). Dr(a).
Prof(a). Dr(a).

Prof(a). Dr(a).

Prof(a). Dr.(a).

Orientador(a) 
ÍNDICE:

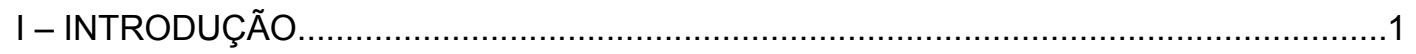

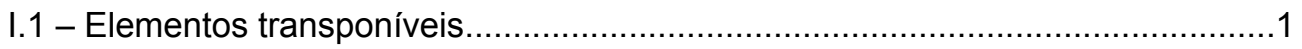

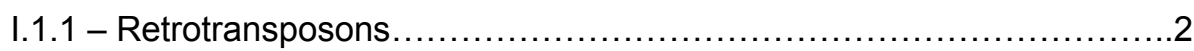

I.2 - Abundância dos retrotransposons............................................................

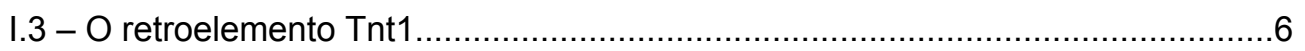

I.4 - Função e regulação dos retroelementos.....................................................

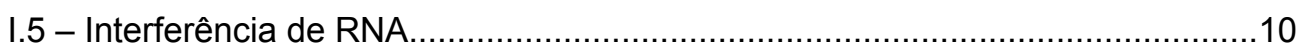

I.5.1 - Silenciamento gênico pós transcricional por inverções repetidas (IR-

PTGS)

I.5.2 - Silenciamento gênico pós transcricional por sequência senso (S-

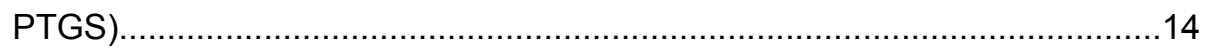

I.5.3 - Regulação pós transcricional microRNA e TAS-iRNA …....................15

II - OBJETIVOS

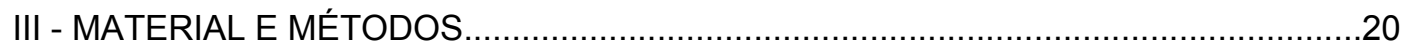

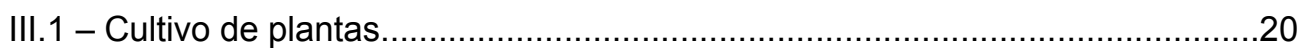

III.1.1 - Material botânico............................................................20

III.1.2 - Solução nutritiva e meio de cultura...............................................20

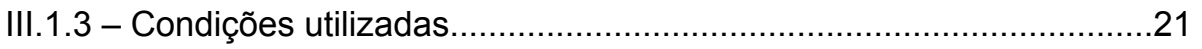

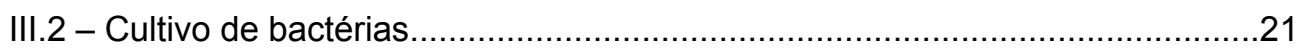

III.2.1 - Cepas bacterianas...........................................................21

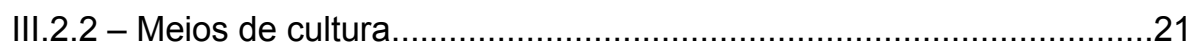

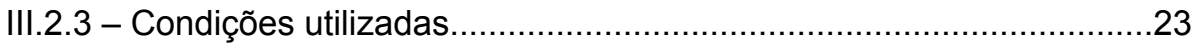

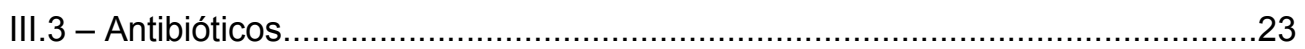

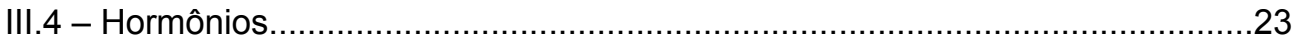

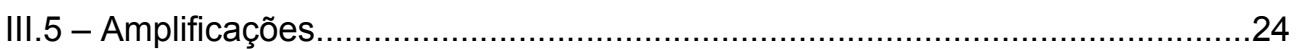

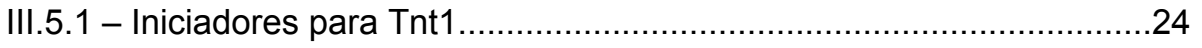

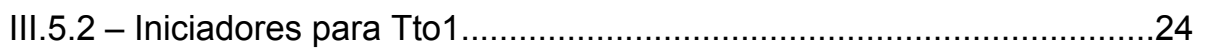

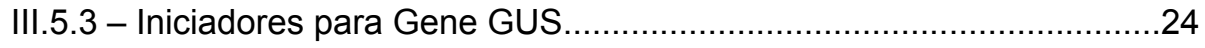

III.5.4 - Condições de reação de polimerização em cadeia..........................24

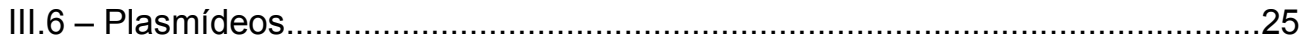


III.7 - Transformação de bactérias competentes por choque térmico. .27

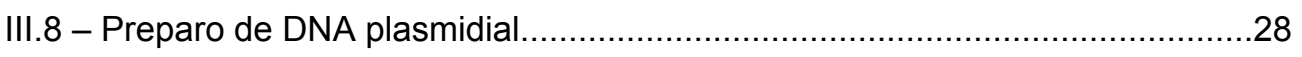

III.8.1 - Preparo de DNA plasmidial em pequena escala (miniprep)............28

III.8.2 - Extração de DNA plasmidial em média escala (Midiprep)...............29

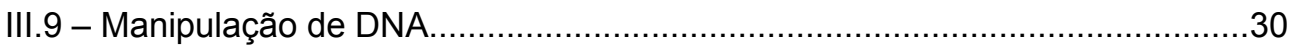

III.9.1 - Hidrólise de DNA com Endonucleases de Restrição.......................30

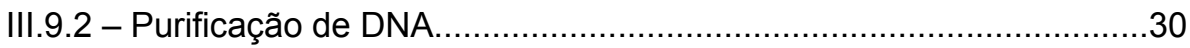

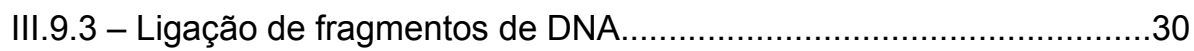

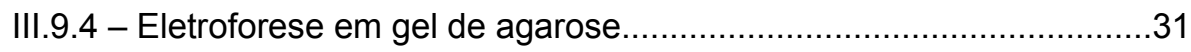

III.10 - Transformação de Agrobacterium tumefaciens por eletroporação..............31

III.11 - Transformação de discos foliares por co-cultura.............................32

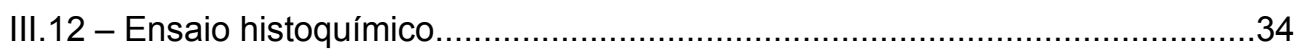

II.13 - Análise da expressão de Tnt1 e Tto1 em Nicotiana tabacum por Northern

Blot. .35

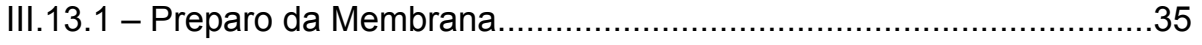

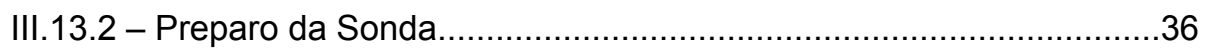

III.13.3 - Hibridação, lavagem e exposição da Membrana.......................37

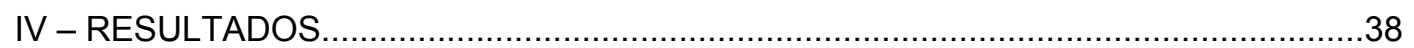

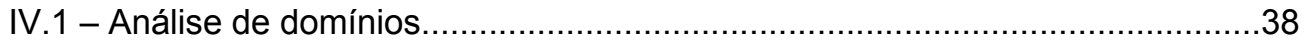

IV.2 - Construções Interferência, Anti-senso e Controle.................................40

IV.2.1 - Amplificação da transcriptase reversa................................40

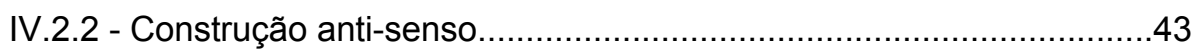

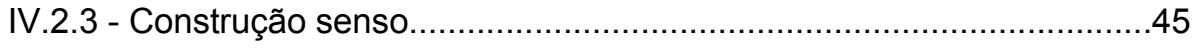

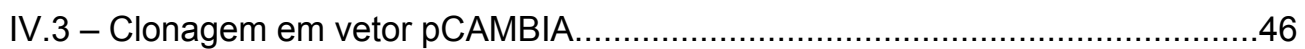

IV.4 - Construção do vetor pBKTnt1RT271asm......................................49

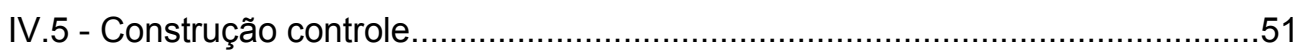

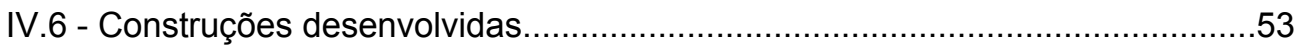

IV.7 - Transformação de tecidos foliares de plantas de fumo...........................54

IV.8 - Experimentos de transformação..................................................55 
IV.10 - Análise de RNA das plantas transformadas..........................................63

V - DISCUSSÃO

VI - RESUMO

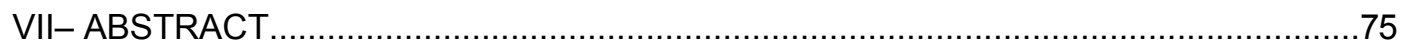

VI - REFERÊNCIAS BIBLIOGRÁFICAS ............................................ 


\section{I - INTRODUÇÃO:}

\section{I.1 - Elementos transponíveis}

A primeira caracterização de elementos transponíveis foi feita pela citogeneticista Barbara McClintock no final da década de 40. Desde então, diversos elementos foram caracterizados nos três domínios: Bacteria, Archea e Eukarya (Stuart-Rogers \& Flavell, 2001; Monteiro-Vitorello et al, 2005).

Os elementos transponíveis são divididos em duas classes segundo o modo de propagação. A classe I é representada pelos retroelementos que em seu ciclo de transposição sintetizam uma fita de cDNA (DNA cópia) a partir do mRNA (RNA mensageiro) intermediário, sendo esta fita de cDNA polimerizada que irá se integrar no genoma em novo local. Já a classe II de elementos é representada pelos transposons que se movem a partir de uma molécula de DNA (ácido desoxiribonucleico) sem utilização de um intermediário de RNA (ácido ribonucleico) (Kumar e Bennetzen, 1999).

Esses elementos são conhecidos por sua habilidade de inserção em diferentes locais no genoma inclusive dentro de outros genes funcionais. Quando essa inserção ocorre, o gene tem sua seqüência alterada podendo resultar em uma proteína com atividade reduzida ou mesmo nula. Estas alterações podem resultar em mudanças fenotípicas (Clegg \& Durbin, 2000) inviabilizando a sobrevivência do organismo. No entanto, o fenômeno da transposição nem sempre é danoso ao organismo. Ela pode ocorrer de forma a rearranjar genes causando variabilidade genética e contribuindo para a evolução dos genomas (Leprince et al, 2001). 


\section{I.1.1 - Retrotransposons}

Os retrotransposons são os elementos mais abundantes dos genomas eucarióticos. Estes elementos, apesar de divergirem quanto a sua organização, possuem dois domínios essenciais que os caracterizam, os domínios Gag e Pol. A região LTR (Long Terminal Repeat) está presente nos retrotransposons que possuem longas repetições diretas nas suas extremidades como pode ser visualizado na figura 1.

Contido na LTR encontra-se o promotor do retroelemento. O domínio Gag codifica para proteínas que estão relacionadas na maturação de outras proteínas e empacotamento do RNA do retroelemento. No domínio Pol estão codificadas todas as proteínas necessárias para o ciclo de transposição como a protease (PR), a integrase (INT), a transcriptase reversa (RT) e a RNAse $H$. As seqüências PBS (Primer Binding Site) e PPT (Polypurine Tracts) são essenciais para o ciclo de replicação e regeneração das LTRs do elemento no momento da transposição. (Kumar e Bennetzen, 1999).

Estes elementos se assemelham muito estruturalmente e funcionalmente com os retrovírus, a diferença é que os retrotransposons não possuem a informação para produção do envelope (env) que nos retrovírus é fundamental para permitir a infecção celular (Flavell et al. 1992; Takeda et al. 2001). Decorrente de sua organização estrutural (figura 1), os retrotransposons apresentam-se distribuídos em dois gupos, os que possuem longas repetições terminais (LTR) e os que não possuem LTR. Aqueles que possuem LTR apresentam seus domínios internos ordenados, seja como Ty1-copia ou Ty3-gypsy. 


\section{LTR retrotransposons}

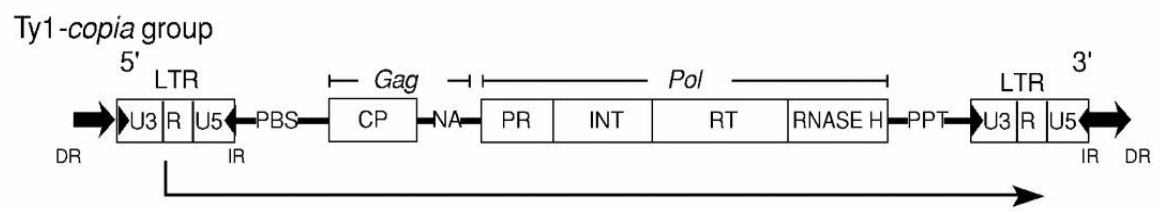

Ty3-gypsy group

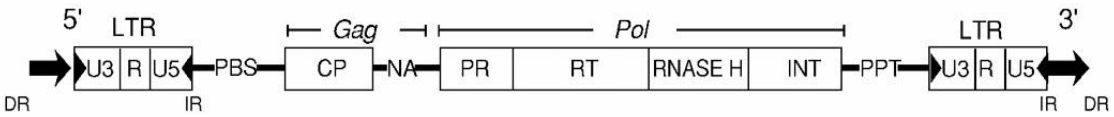

\section{Non-LTR retrotransposons}

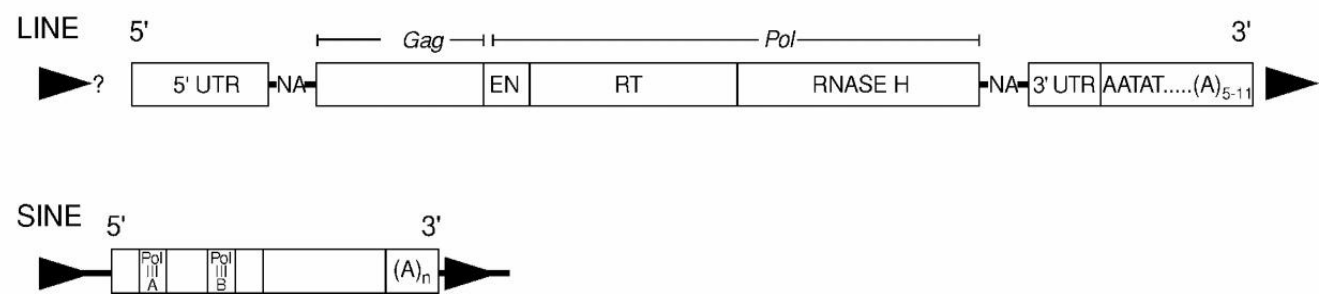

Figura 1- Representação dos grupos de retrotransposons com seus respectivos domínios (extraído de Kumar e Bennetzen, 1999)

Os elementos destas duas classes são conhecidos por usarem partículas ribonucleoprotéicas como intermediários no seu ciclo de transposição. As proteínas estruturais destas partículas são codificadas pela Gag que geram um microambiente adequado a reverso transcrição de mRNAs. Dentro das partículas encontram-se transcritos do retrotransposon e diversas enzimas: protease, transcriptase reversa, ribonuclease $H$ e integrase. A transcriptase reversa (RT) codificada pelo domínio $r t$, é responsável por sintetizar uma fita de DNA a partir de RNA do retrotransposon, e assim formando um híbrido de RNA - DNA. A degradação parcial deste híbrido RNA - DNA é necessária para que a RT conclua seu trabalho e forme a fita complementar. A integrase, que é codificada pelo 
domínio int, auxilia a inserção da nova cópia do elemento no genoma (Flavell, 1995).

Donor DNA with retrotransposon

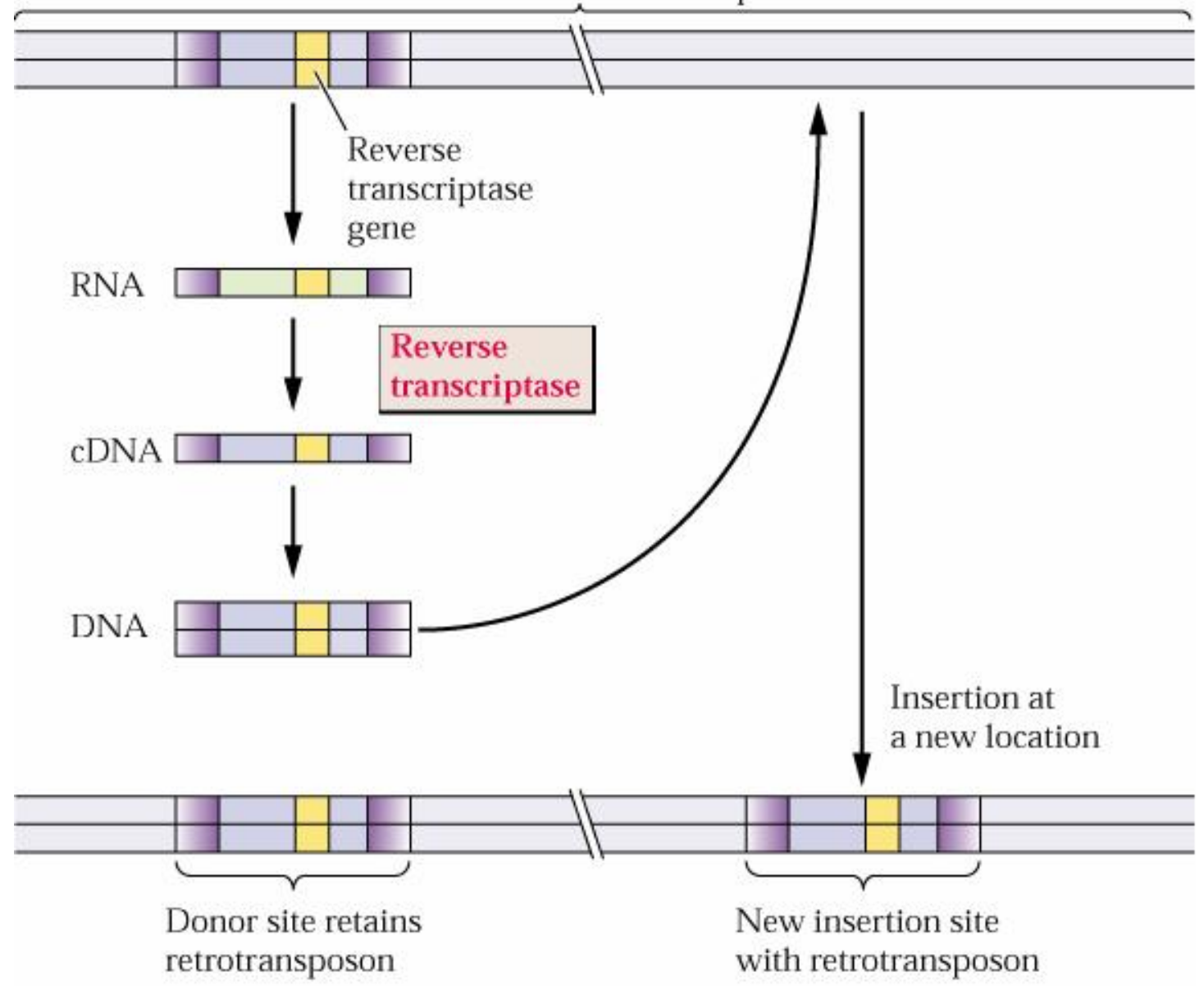

Figura 2: Representação do modo de transposição de um retroelemento.O retroelemento é transcrito do genoma gerando um mRNA com todos os seus domínios. O mRNA é traduzido em diversas proteínas das quais uma delas é a transcriptase reversa. Esta proteína atua no mRNA do elemento formando um cDNA que por sua vez vai sofrer a ação de uma DNA polimerase que completará a simples fita em dupla fita. Esta dupla fita será realocada em outro local do genoma com auxílio da integrase concluindo assim uma nova cópia do elemento. (extraído de Buchanan, 2000).

Os retrotransposons que não possuem LTR podem ser divididos em dois grupos os chamados LINES ("Long Interspersed Repetitive Elements") e SINES ("Short Interspersed Repetitive Elements"). Estes dois grupos diferem em suas estruturas como mostrado na figura 1. 
O elemento LINE apresenta uma estrutura semelhante aos retrotransposons LTR tendo os domínios Gag e Pol, mas não possuem as LTRs terminais. Já nos elementos SINEs, seu modo de organização difere dos outros elementos uma vez que não possui os domínios Gag e Pol como no elemento descrito acima. Os elementos LINES foram encontrados em todos os grupos do reino vegetal e os SINES foram descritos apenas em angiospermas (Kumar e Bennetzen, 1999).

\section{2 - Abundância dos retrotransposons}

Devido aos retrotranspons possuírem um sistema de transposição replicativo, acredita-se que esses elementos sejam agentes importantes responsáveis pelo aumento do tamanho do genoma de eucariotos e proporcionem mutações devido a suas inserções. (Takeda et al. 2001).

Em Arabdopsis thaliana, que possui um genoma considerado pequeno, foram anotados 2355 genes relacionados a retrelementos (Haas et al, 2005). Em Liliacea, aproximadamente $90 \%$ do genoma é formado por elementos transponíveis (Sabot \& Schulman, 2006). Em milho, um estudo feito com a região Adh1 que possui $280 \mathrm{~kb}$, mostrou que cerca de $62 \%$ desta região é representada por retroelementos. Foram encontrados 23 diferentes retroelementos pertencentes a 10 famílias distintas (Gaut et al, 2000). Nas gramíneas, os retroelementos representam cerca de $50 \%$ a $80 \%$ do genoma. Já no genoma de arroz, cerca de 80 mega bases é representado por retroelementos. Isso corresponde a mais que $20 \%$ do genoma (Feschotte et al, 2002; Chaparro et al, 2006)

Em humanos, esta representação é de aproximadamente $45 \%$ do genoma (Feschotte et al, 2002). Na maioria dos genomas de mamíferos, os 
elementos LINES e SINES são os mais abundantes, representando aproximadamente $35 \%$ do genoma com mais de 100.000 cópias de cada tipo de elemento. Os elementos com LTR do grupo Ty1-copia são raros ou ausentes. Contrastando com os animais, os elementos LINES, SINES, Ty3Gypsy e Ty1-copia são encontrados abundantemente nas plantas. (Kumar e Bennetzen, 1999).

\section{I.3 - O retroelemento Tnt1}

Este elemento foi descoberto por Grandbastien e colaboradores em 1989 graças à sua atividade em plantas de fumo. Nestas plantas, existem dois genes homólogos da nitrato redutase (nia 1 e nia 2) e para indução da deficiência da nitrato redutase, os dois genes presentes precisam ser inoperantes simultaneamente. Para a realização do projeto, foram desenvolvidas células haplóides, que possuíam um dos alelos mutados de forma estável, de modo que um evento de transposição para dentro do alelo funcional, inativaria o gene da nitrato redutase. Assim, quando as células fossem selecionadas através do clorato, esta substância não seria redusida a clorito pelo gene da nitrato redutase, resultando num crescimento celular normal e possibilidade de regeneração de novos indivíduos. Os indivíduos regenerados foram analisados molecularmente e foi observado que nas plantas selvagens, a banda referente ao gene nia quando digerido com a enzima Eco Rl, possuia tamanho de 4,2 quilobases, enquanto que os mutantes que possuíam resitência a clorato, apresentavam uma banda de 9.4 quilobases, o que evidenciava a transposição deste elemento para dentro do gene, motivo pelo qual o gene estava inativo e a planta se apresentava resistente ao clorato. O retroelemento inserido no gene da nitrato redutase foi 
clonado, sequenciado e analisado recebendo o nome de Tnt1 (Transposon of Nicotiana tabacum). Esse retrotransposon possui 5334 pares de base e está classificado como um elemento da classe Ty1-copia. É um retroelemento ativo, como se pode notar pela própria estratégia usada para seu isolamento. Nota-se atividade em tecidos estressados, como tecidos danificados, em contato com extratos fúngicos, em regeneração, congelados, em contato com ozônio, baixas tempreraturas e tratados com substâncias como $\mathrm{CuCl}_{2}$, que induz a produção de fitoalexina, substância sinalizadora para resposta de defesa na planta. (Mhiri et al., 1997; Melayah et al., 2001). Recentemente foi descoberto que o elemento Tnt1 responde a desidratação e a $A B A$. A resposta a todos estes estímulos pode ser entendida pela sua região reguladora, a região $L T R$, que possui motivos similares a motivos envolvidos na ativação de genes de defesa do organismo. A hipótese sugerida seria que estes elementos, mais que uma modificação genômica, eles influenciariam a expressão gênica na resposta a um grande número de adversidades (Marie-Angele et al., 2005).

\section{I.4 - Função e regulação dos retroelementos}

De um modo geral, estes elementos repetitivos são considerados parasitas ou DNA lixo, não havendo uma função claramente atribuída. Sabese que os retroelementos podem ter contribuído para um aumento no tamanho do genoma dos organismos (Kumar e Bennetzen, 1999) e que podem causar variabilidade genética ou se deslocar de um lugar para outro afetando genes do hospedeiro alterando sua funcionalidade (Marillonnet et al. 1997; Courtial et al. 2001; Leprince et al. 2001; Grandbastien et al. 2005). 
Em função de sua atividade transposicional com potencial impacto sobre a atividade dos genes, observa-se nos diversos organismos a existência de um controle fino sobre a mobilidade dos elementos. O primeiro é um mecanismo de inibição transcricional que impede que a maquinaria de transcrição seja acoplada ao elemento através de metilação do mesmo. Sendo assim, não há a transcrição do elemento impedindo a formação do mRNA (Scortecci et al, 1997; Hirochika et al., 2000; Miura et al., 2001)

O segundo é um mecanismo de controle pós-transcricional. Neste sistema de inibição, ocorre normalmente a transcrição do elemento, mas devido a ação de pequenos RNAs de interferência, o mRNA provindo do elemento é degradado antes de ser traduzido (Waterhouse et al, 2001; Komatsu et al, 2003).

Alternativamente à hipótese de DNA lixo, questiona-se atualmente que estes elementos possam ser responsáveis pela formação de novos genes. A sua capacidade de incorporação de sequências de outros genes e sua movimentação pelo genoma levando esses fragmentos de DNA, podem ter contribuído para tal formação (Bennetzen, 2005)

Um estudo completo comprovando a metilação do elemento foi realizado em Arabdopsis thaliana por Hirochika e colaboradores (Hirochika et al, 2000) tendo como alvo de estudo o elemento Tto1 encontrado em fumo que através de técnicas de transgenia, foi passado para o organismo em estudo. O trabalho caracterizou que a expressão deste retrotransposon nestas plantas aumentava quando as plantas eram regeneradas, mas após a regeneração, esses elementos eram silenciados e não se notavam eventos de transposição. Comparando-se o nível de metilação do elemento na geração que os recebeu com seus descendentes por autofecundação, notou- 
se que os elementos estavam ainda mais metilados o que levou os autores a inferirem que a metilação do elemento aumentava progressivamente através das gerações. Em busca do motivo do silenciamento, géis para detecção de metilação foram feitos com várias gerações das plantas regeneradas e que tinham o retrotransposon Tto1 silenciado. O resultado foi uma alta metilação dos elementos Tto1 e essa metilação aumentava conforme se avançava nas gerações. Como controle positivo, os retrotransposons Tto1 foram inseridos em plantas que apresentavam deficiência em metilação gênica, os mutantes $d d m 1$. Nestes mutantes foi visto que havia uma intensa transposição de Tto1 e posteriormente comprovou-se que os elementos não estavam metilados. Este resultado foi crucial para elucidar que a metilação estava associada ao controle de atividade do retrotransposon. Outro resultado importante foi que na análise de plantas com pequenos números de cópias do retrotransposon não se notava metilação do elemento, enquanto que em plantas que possuíam muitas cópias deste elemento, este aparecia altamente metilado. Este trabalho comprovou que a metilação gênica se aplica aos retroelementos impedindo sua transcrição e possível transposição para outro lugar no genoma.

Estudos realizados com os promotores dos elementos Tnt1 e Tto1, associam esses elementos com resposta a estresse em fumo. Os trabalhos com Tnt1 e Tto1 utilizaram os promotores desses elementos fusionados a genes repórteres como o gene gus. Com dessas construções realizadas, a atividade dos promotores testados pôde ser visualizada. A atividade do 
promotor se mostrou intensa em situações de estresse seja físico (congelamento, cortes, esmagamento) ou químicos (Metil-jasmonato, $\mathrm{CuCl}_{2}$, herbicidas, eliciadores fúngicos) ( Mhiri et al.1996; Mhiri et al. 1997; Takeda et al. 1998).

Devido ao estudo mais detalhado da região promotora do elemento Tnt1, especificamente a região U3, foram descobertos vários motivos em comum com genes de fumo associados à regeneração e defesa (Grandbastien et al, 2005). Existem sequências homólogas no promotor do retroelemento à genes do organismo ativado na presença de eliciadores fúngicos, à genes que respondem a hormônios que são liberados em situações de estresse como etileno e à genes que são ativados em situações de anaerobiose (Grandbastien et al, 2005).

Estando este retroelemento provido de tantos motivos que respondem a diversas situações de estresse, algumas especulações sugerem possíveis funções para Tnt1:

1 - Este elemento ocupa um papel importante nessas situações e desempenha alguma função que auxilie a planta a superar a situação de estresse. 
2 - Este elemento é um parasita especializado que se utiliza da situação estresse para se amplificar.

\section{I.5 - Interferência de RNA}

O mecanismo de interferência de RNA em plantas ainda não está completamente esclarecido. Durante o desenvolvimento do presente projeto, muitas descobertas foram feitas sobre o processo de interferência de RNA. Sabe-se hoje que esse sistema possui quatro variantes que levam a degradação do RNA mensageiro dos genes alvo: IR-PTGS (Inverted Repeat Post Transcriptional Gene Silencing), S-PTGS (Sense - Post Transcriptional Gene Silencing), miRNA (Micro RNA) e TAS-iRNA (Transacting Small Interfering RNA) (Brodersen \& Voinnet, 2006). Já foi observado que em plantas, existe um controle genético natural feito por interferência de RNA. Esse controle regula uma série de funções nas plantas, entre elas, tempo de floração, resposta a estresse, resposta a auxina e desenvolvimento das folhas (Mallory e Vaucheret, 2006). O sistema também é considerado uma defesa natural das plantas contra ataque virais (Lindbo e Dougherty, 2005). Independente da nomeclatura que receba, o mecanismo de interferência de 
RNA caracteriza-se pela clivagem específica de uma molécula de RNA mensageiro que compartilha de homologia de seqüência com pequenas moléculas de RNA (20-25 nucleotídeos) produzidas a partir de diferentes origens como veremos a seguir. A clivagem do mensageiro resulta na perda de função por ausência de substrato para tradução.

O mecanismo de geração destas pequenas moléculas de RNA de interferência depende da origem do mensageiro a ser clivado (gene endógeno, elemento de transposição, vírus ou transgene) sendo que todos deverão ser carregados ao complexo RISC (RNA Interference Silence Complex), constituído de proteínas da família AGO, para realização da clivagem final. Deve-se portanto, considerar duas etapas no processo, quais sejam:

I. Biogênese da molécula que será incorporada a proteínas da família AGO

Uma molécula de mRNA defeituosa (sem proteína CAP ou cauda poliA) ou estranha ao organismo (RNA viral ou transgene) é reconhecida por uma RNA polimerase. Esta RNA polimerase atua no RNA simples fita transformando-o em RNA dupla fita (dsRNA) que vai iniciar o processo de interferência de RNA sendo reconhecida pela enzima DICER. Após seu reconhecimento, este mRNA será processado pela enzima em pequenos fragmentos de RNA dupla fita que contém de 20 a 25 nucleotídeos (siRNAs) e que apresentam suas porções terminais 3' não pareadas. Estes fragmentos são metilados por intermédio de uma metil-transferase, e ficam então aptos a 
serem reconhecidos pelo complexo protéico RISC (proteínas da família AGO) que é o verdadeiro responsável pela degradação de um mRNA alvo.

II. Mecanismos associados à função biológica do siRNA

O complexo RISC reconhece os pequenos RNAs dupla fita (siRNAs) processados pela DICER e anexa uma de suas fitas aleatoriamente. Anexando a fita anti-senso o complexo fica apto a reconhecer o mRNA alvo, pois possui uma fita complementar a ele podendo se parear. Quando acontece o pareamento, o complexo degrada o mRNA alvo impedindo sua tradução (figura 3) (Dykxhoorn et al,2003). Este processo de interferência de RNA gera uma inibição transcricional do gene que deu origem ao mRNA. O siRNA pode guiar o complexo RISC até o núcleo e parear com a sequência complementar no DNA. Este pareamento leva o complexo a mudar a conformação do DNA no local através da metilação das histonas impedindo que o gene seja transcrito. (Mathieu \& Bender, 2004; Vaucheret, 2006) 


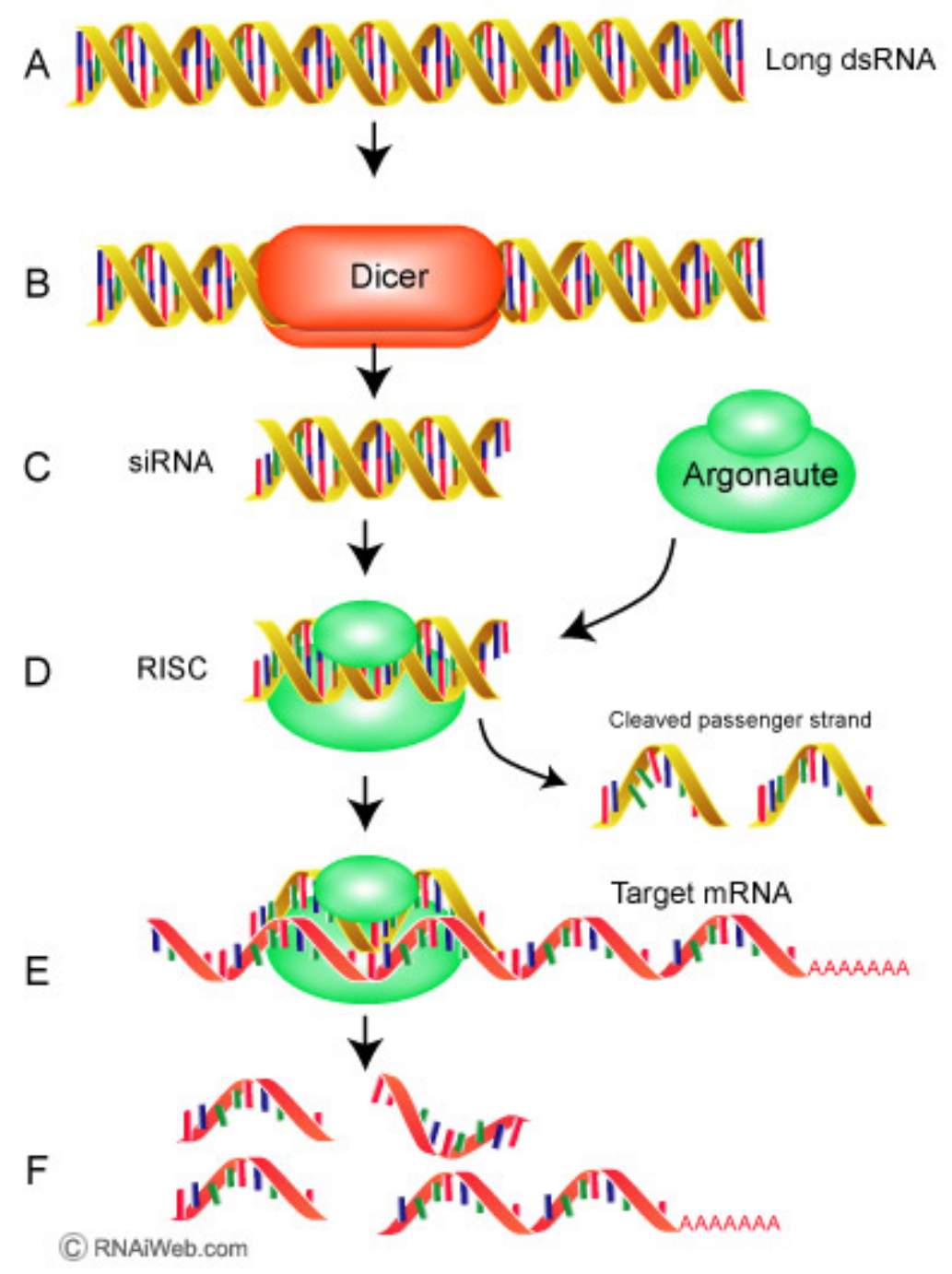

Figura 3: Representação geral do sistema de RNAi. (rnaiweb.com)

\section{I.5.1 - Silenciamento gênico pós transcricional por inverções repetidas (IR-PTGS)}

Neste processo de indução de RNAi o fenômeno é iniciado pela produção de um RNA dupla fita (dsRNA) originado pela presença no genoma de cópias gênicas inseridas em tandem nos sentidos senso e anti-senso, que quando transcritas darão origem a um dsRNA que desencadeará o sistema de inibição IR-PTGS. Este sistema também pode ser ativado através de construção gênica na qual são clonadas sequências complementares que 
fazem parte de um gene alvo presente no genoma. Este tipo de construção foi utilizada no presente trabalho para inibição do retroelemento Tnt1 e potencialmente Tto1.

O sistema IR-PTGS é a base do sistema de interferência em plantas e dele derivam dois tipos de siRNA (Short Interfering RNAs) (Hamilton et al, 2002): Os siRNAs com 21 nucleotídeos são os responsáveis pela degradação direta do RNA alvo, e os siRNAs de 24 nucleotídeos são responsáveis por mudanças conformacionais na cromatina.

O dsRNA pode ser reconhecido e processado por dois tipos de enzimas Dicer like (DCL). Se for processado pela enzima DCL4, haverá a formação de siRNAs de 21 nucleotídeos, e se processado pela enzima DCL3, haverá a formação de siRNAs de 24 nucleotídeos. Ambos os siRNAs sofrem metilação em seus terminais 3' pela ação do complexo HEN-1 (metil transferase) (figura 4a). Esta estrutura com os terminais 3' metilados são fundamentais para que os siRNAs sejam reconhecidos pelo complexo AGO-1 loaded RISC (RNA Interference Silence Complex), e uma de suas fitas sejam incorporadas ao complexo. Esta fita é responsável por guiar o complexo AGO-1 até um mRNA complementar, o qual será clivado e posteriormente degradado.

\section{I.5.2 - Silenciamento gênico pós transcricional por sequência senso (S- PTGS)}

Este sistema foi estudado em um indivíduo de Arabdopsis thaliana que por mutação, perdeu a atividade da proteína XRN4. Esta enzima possui atividade exonucleolítica 5' - 3' e têm por função degradar RNAs sem CAP. A 
falta desta proteína causa o acúmulo de RNAs defeituosos e este acúmulo causa um desvio no processo de degradação. Os RNAs defeituosos são transformados em RNAs dupla fita por um complexo protéico formado por RDR6 (RNA Dependent RNA polimerase), SGS3 (Uma proteína ainda com função desconhecida), SDE3 (uma helicase RNA) e possivelmente WEX (Rnase D exonuclease). As duplas fitas de RNA são processadas por uma enzima DICER-like, provavelmente a proteína DCL4, que vai degradar a dupla fita de RNA em fragmentos de 21 nucleotídeos. Estes fragmentos são metilados pela proteína HEN1 formando os siRNAs. Estes siRNAs podem entrar em 2 vias. Na primeira ele poderá ser acoplado ao AGO1 e portanto guiar o complexo até um RNAm homólogo que vai ser degradado quando acontecer o pareamento. $\mathrm{Na}$ segunda seria o siRNA que parearia com o RNAm defeituoso servindo de iniciador para o complexo RDR6, SGS3, SDE3 que por sua vez transformaria o mRNA defeituoso e RNA dupla fita e entraria novamente no sistema de formação de siRNAs. Esta última via confere uma amplificação de sinal ao processo produzindo maior quantidade de siRNA (figura 4b). Este sistema também é conhecido pela regulação natural de retroelementos em outros organismos, como em C. elegans, evitando efeitos deletérios (Robert et al, 2004) e em plantas como uma defesa contra infecção viral.

\section{I.5.3 - Regulação pós transcricional microRNA e TAS-iRNA}

Sabe-se hoje que as plantas são aptas a realizar controle de expressão gênica através de inibição pós-transcricional. Existem dois tipos de controle pós transcricional conhecidos e complementares que são: o miRNA (Micro RNA) e o TAS-iRNA (Trans-acting siRNA). Estes dois sistemas de 
silenciamento gênico foram caracterizados em Arabdopsis thaliana, e tem como objetivo a regulação da expressão gênica. Vários genes que determinam diversos aspectos na planta são regulados por estes sistemas como, por exemplo, forma da folha (Palatnik et al, 2003), tempo de floração, e número de órgãos florais (Aukerman e Sakai, 2003; Baker et al, 2005) e até o próprio sistema microRNA é controlado pela inibição pós transcricional (Mallory e Vaucheret, 2006).

No sistema de inibição por micro RNA (figura 4c), a maioria dos miRNAs estão localizados flanqueados a genes que codificam proteínas ou dentro de íntrons. Muito deste sistema ainda continua desconhecido, mas sabe-se que a transcrição do sítio onde se encontra o miRNA pela RNA polimerase II dá origem ao Pri-miRNA (Primary miRNA), que vai desencadear o processo. A combinação dos complexos HYL1, DCL1, e HEN1 processa e metila o pri-miRNA transformando-o em miRNA maduro (miR). Dentro do núcleo, o miR pode seguir dois caminhos: ou se complexa ao AGO1 e pareia a um mRNA alvo que entrará na via tasi-RNA, ou o complexo AGO1/miR promove a metilação do gene alvo no DNA do organismo.

O miR pode também ser exportado do núcleo através da exportina HASTY (exportina homóloga à exportina 5). Por este caminho, o miR é incorporado ao AGO1e pode seguir duas vias: a primeira (Figura 4c direita), é a degradação do mRNA alvo através da poliuridinação do terminal 5', que vai ser reconhecido pela XRN4 e rapidamente degradado. A segunda via consiste na inibição da transcrição, provavelmente em sua iniciação.

O sistema tasi-RNA complementa o sistema miRNA. O sistema tasiRNA começa com o complexo AG01/miR pareado com o mRNA alvo (figura 4d). O complexo cliva o mRNA alvo em duas partes das quais uma serve de 
molde para RDR6 qua vai complementar este RNA clivado trasformando-o em um dsRNA. Este dsRNA vai ser processado pelo complexo DCL4 que o fragmentará em pequenos RNAs de 21 nucleotídeos e estes pequenos RNAs vão ser metilados pela ação do complexo HEN1 que os transformará em siRNAs. Os siRNAs vão se complexar ao AGO1 e através da sequência de base do siRNA, o complexo irá encontrar o mRNA alvo e o clivará evitando sua transcrição. 


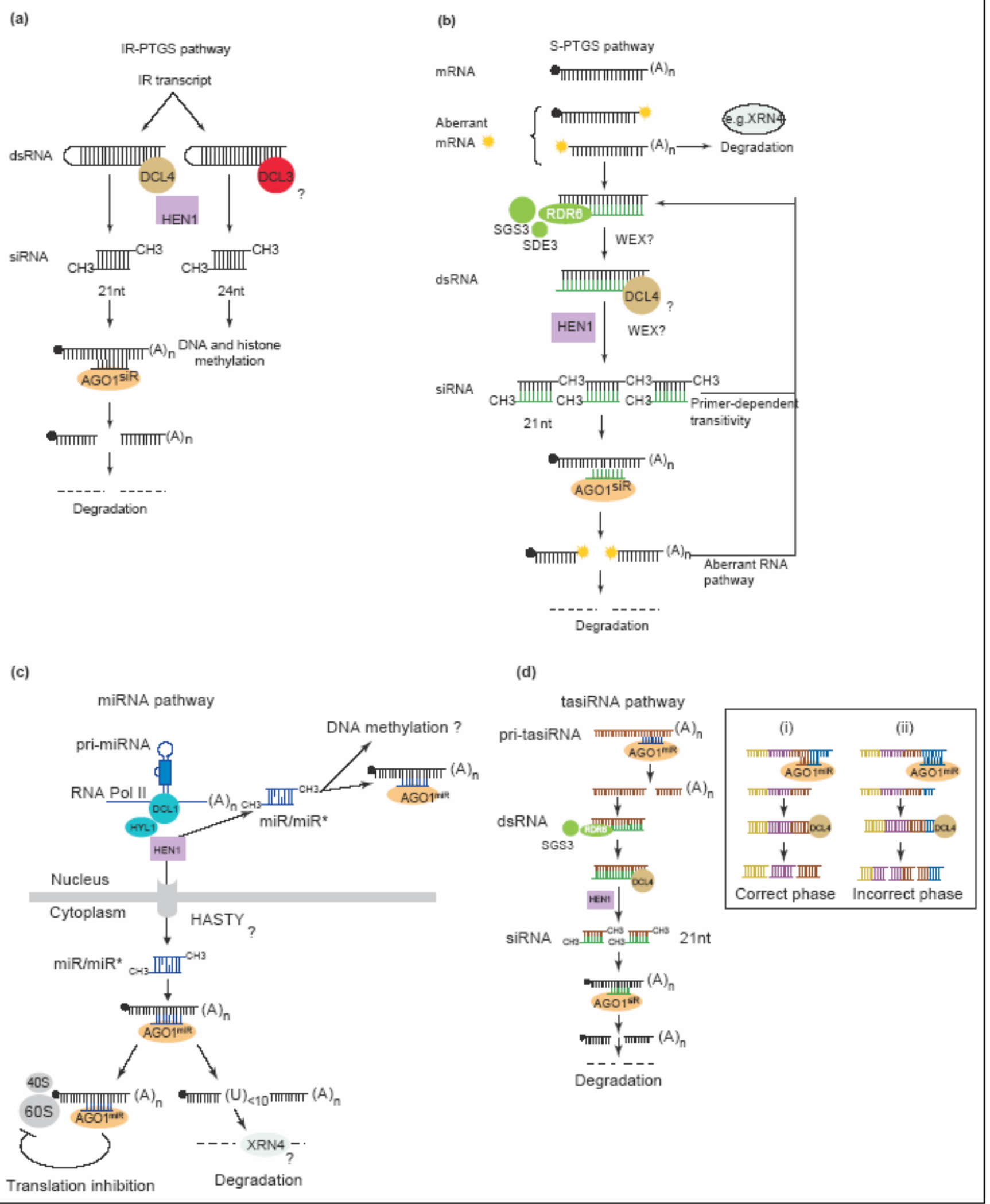

Figura 4: Representações dos sistemas de inibição pós-transcricional presente em plantas (extraído de Brodersen e Voinnet, 2006) 


\section{II - OBJETIVOS}

Com o objetivo de desvendar o papel potencial de retrotransposons em plantas, pretende-se a inativação específica por meio de interferência de RNA de retrotransposons da família Tnt1 e eventualmente da família Tto1. Ambos os elementos encontram-se transcricionalmente e transposicionalmente ativos no momento da regeneração de tecidos vegetais, portanto a partir da construção de um vetor específico capaz de induzir silenciamento gênico por interferência de RNA será avaliado:

1 - Potencial de regeneração de discos foliares de fumo.

2 - Fenótipo das plantas regeneradas.

3 - Expressão dos elementos nas plantas regenerantes. 
III - MATERIAL E MÉTODOS

III.1 - Cultivo de plantas

\section{III.1.1 - Material botânico}

Foram utilizadas plantas de Nicotiana tabacum variedade XFHD8 em todos os experimentos. A partir das construções gênicas realizadas neste estudo, foram geradas linhagens de fumo genéticamente modificiadas: pBKTnt1RT271ri, pBKTnt1RT470as, pBKTnt1RT271asm e pBKTnt1RTc.

III.1.2 - Solução nutritiva e meio de cultura

Meio MS 20 (Murashige \&Skoog, 1962)

$\begin{array}{ll}\text { Macronutrientes (Sigma M0654) } & 50 \mathrm{ml} / \mathrm{l} \\ \text { Micronutrientes (Sigma M0529) } & 100 \mathrm{ml} / \mathrm{l} \\ \text { Vitaminas MS (Sigma-M3900) } & 1 \mathrm{ml} / \mathrm{L} \\ \text { Sacarose } & 20 \mathrm{~g} / \mathrm{l}\end{array}$

Para meio sólido: 6,0 g/l de Phytagar (Gibco BRL), pH 5,6 ajustado com KOH $1 \mathrm{~N}$. 
Meio MS 30

Mesma composição do meio MS 20, mas com $30 \mathrm{~g} / \mathrm{l}$ de sacarose.

Vitaminas de Nitsch (500x)

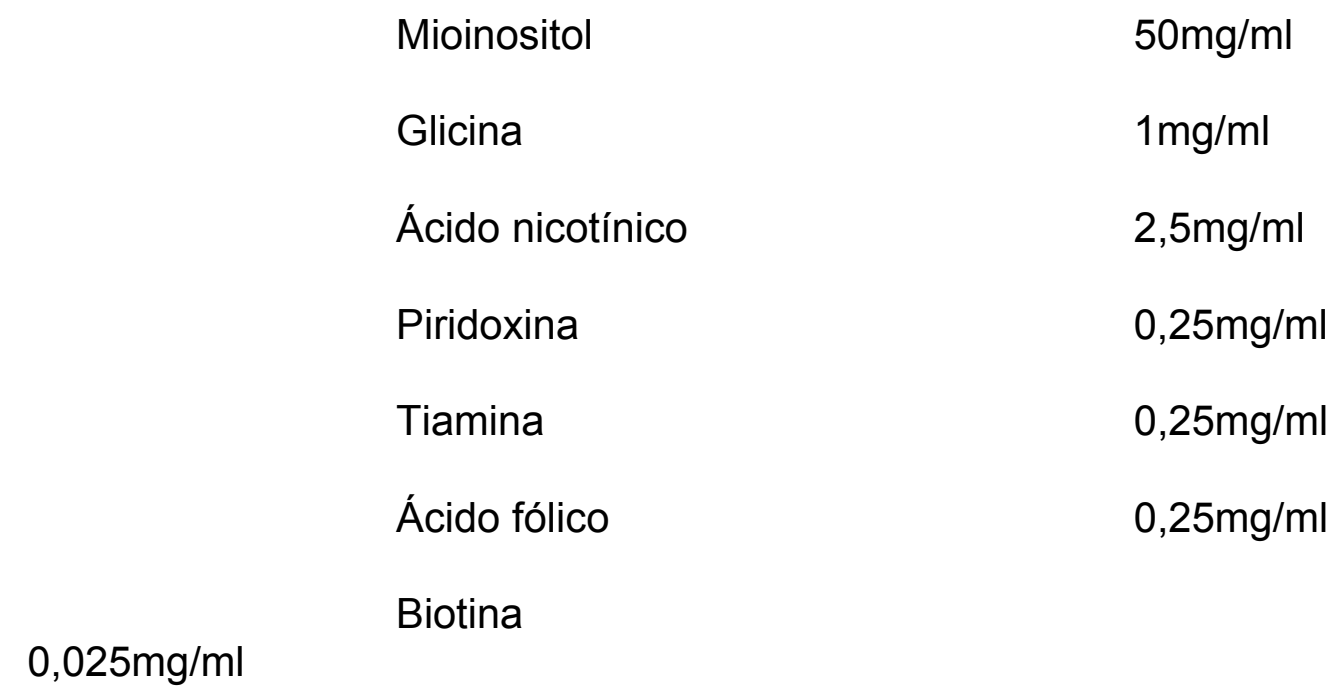

Essa solução é preparada com água ultrafiltrada previamente esterilizada em autoclave $\left(120^{\circ} \mathrm{C}, 1 \mathrm{~atm}, 15\right.$ minutos $)$ e armazenada a $-20^{\circ} \mathrm{C}$.

\section{III.1.3 - Condições utilizadas}

Estas plantas são cultivadas em condições livre de contaminação (frascos Magenta ${ }^{\circ}$ ) em meio de cultura MS20 ou MS30. Estas plantas são 
repicadas num intervalo de aproximadamente 30 dias nos quais o frasco e o meio de cultura são renovados. As plantas ficaram alocadas em sala de cultura com fotoperíodo de 12 horas e temperatura de $22-25^{\circ} \mathrm{C}$.

\section{III.2 - Cultivo de bactérias}

\section{III.2.1 - Cepas bacterianas}

Escherichia coli:

Genótipo DH10B: possibilita a transformação com material genético exógeno através de choque térmico.

Agrobacterium tumefasciens:

Genótipo LBA4404: possui cromossomo originário da linhagem TiAch5, apresentando resistência ao antibiótico rifampicina. Plasmídeo Ti (pAL4404) contém genes de resistência a espectinomicina e estreptomicina e de catálise de octopina. Essa cepa possui a capacidade de transferir para células vegetais um t-DNA localizado em seu interior. Ela é desarmada, ou 
seja, não possui informação genética que causa a formação de tumor quando introduzida na planta.

\section{III.2.2 - Meios de cultura}

Para cultivo de bactérias $E$. coli foi utilizado o meio LB:

\section{Meio LB}

$\begin{array}{lc}\text { Bactotriptona } & 1 \% \\ \text { Extrato de levedura } & 0,5 \% \\ \mathrm{NaCl} & 0,5 \%\end{array}$

$\mathrm{O}$ pH é ajustado para 7,4 com NaOH 10N. Para meio sólido são adicionados $20 \mathrm{~g} / \mathrm{l}$ de ágar bacteriológico.

Para cultivo da cepa de Agrobacterium tumefasciens foi utilizado o meio AT:

Meio AT:

Extrato de levedura

$0,5 \%$ 
Sacarose

$0,2 \%$

Sulfato de amônia

$0,2 \%$

Sais AT

$1 \mathrm{x}$

Sais AT 2x:

$\begin{array}{lll} & \mathrm{KH}_{2} \mathrm{PO}_{4} & 21,8 \mathrm{~g} / \mathrm{l} \\ 0,32 \mathrm{~g} / \mathrm{l} & \mathrm{MgSO}_{4} .7 \mathrm{H}_{2} \mathrm{O} & \\ 0,01 \mathrm{~g} / \mathrm{l} & \mathrm{FeSO}_{4} .7 \mathrm{H}_{2} \mathrm{O} & \\ & \mathrm{CaCl}_{2} .2 \mathrm{H}_{2} \mathrm{O} & 0,02 \mathrm{~g} / \mathrm{l} \\ & \mathrm{MnCl}_{2} .4 \mathrm{H}_{2} \mathrm{O} & 0,004 \mathrm{~g} / \mathrm{l}\end{array}$

$\mathrm{pH}$ ajustado para $7,5 \mathrm{com} \mathrm{KOH} 1 \mathrm{~N}$.

O estoque de sais AT 2x é preparado com água destilada, esterilizado em autoclave $\left(120^{\circ} \mathrm{C}, 1 \mathrm{~atm}, 15\right.$ minutos $)$ e armazenado a $4^{\circ} \mathrm{C}$

\section{III.2.3 - Condições utilizadas}

As bactérias da espécie E. coli foram cultivadas a $37^{\circ} \mathrm{C}$ por 10 a 16 horas e as do gênero Agrobacterium a $28{ }^{\circ} \mathrm{C}$ por 20 a 48 horas, em estufas ou câmaras agitadoras. Repiques eram realizados mensalmente em meio sólido contendo os antibióticos adequados, e as bactérias eram 
armazenadas a $4^{\circ} \mathrm{C}$. Foram formados estoques bacterianos em glicerol $50 \%$ e o estoque mantido a $-70^{\circ} \mathrm{C}$.

\section{III.3 - Antibióticos}

\section{Soluções estoque:}

\begin{tabular}{|c|c|}
\hline Ampicilina 100mg/ml & Dissolvida em água ultrafiltrada \\
\hline Cefotaxime $100 \mathrm{mg} / \mathrm{ml}$ & Dissolvida em água ultrafiltrada \\
\hline Rifampicina 50ng/ml & Dissolvida em metanol \\
\hline Higromicina $50 \mathrm{mg} / \mathrm{ml}$ & Dissolvida em água ultrafiltrac \\
\hline Cloranfenicol 34mg/ml & Dissolvido em etanol \\
\hline
\end{tabular}

Os estoques de antibiótico foram esterilizados em filtro Millipore (malha de $45 \mu \mathrm{m}$ ) e armazenados a $-4^{\circ} \mathrm{C}$.

\section{III.4 - Hormônios}

$$
\text { 6BA (BAP) } 5 \mathrm{mM} \quad \text { Dissolvido em água ultrafiltrada }
$$

\section{III.5 - Amplificações}


III.5.1 - Iniciadores para Tnt1

RT1Bam-F: 5' CGGGATCCATCTCAGCAGAAGTACAT 3' (3901 a 3918).

RT2Cla-R: 5' CCATCGATACTTCCCAATGTTCC 3' (4121 a 4143)

RT3Cla-R: 5 ‘ GCATCGATGCAACGCACTTTTGCAAC 3’ (4321 a 4340)

RT1Xho-F: 5' CCGCTCGAGATCTCAGGAGAAGTACA 3' (3901 a 3918)

RT2Kpn-R: 5' GGGGTACCACTGCTTCCCAATGTTCC 3' (4121 a 4143)

RT3Kpn-R: 5' GGGGTACCGCAACGCACTTTTGCAAC 3' (4321 a 4340)

III.5.2 - Iniciadores para Tto1

Tto1-F: 5' GATTGTTGCGGCTTGAAAA 3' (4586 a 4604)

Tto1-R: 5' GCATCATTGCTTACCTGTC 3' (4760 a 4778)

III.5.3 - Iniciadores para Gene GUS

GUS A: 5' CCTTACGCTGAAGAGATGCT 3'

GUS B: 5' GGCAATACTCAACATCACCA 3'

III.5.4 - Condições de reação de polimerização em cadeia

Para $50 \mu$ de reação, foram utilizados $30 \mathrm{ng}$ de DNA plasmidial, $50 \mathrm{mM}$ de $\mathrm{MgCl}_{2}, 100 \mathrm{mM}$ de cada dNTP, 20pmol de cada iniciador e 1 unidade de Taq DNA polimerase (Invitrogen Life Technologies). A amplificação foi 
realizada em 35 ciclos de $1^{\prime}\left(94^{\circ} \mathrm{C}\right), 1^{\prime}\left(55^{\circ} \mathrm{C}\right), 2^{\prime}\left(72^{\circ} \mathrm{C}\right)$, com um período inicial de $5^{\prime}\left(94^{\circ} \mathrm{C}\right)$ e extensão final de $5^{\prime}\left(72^{\circ} \mathrm{C}\right)$.

\section{III.6 - Plasmídeos}

PBSX1: Plasmídeo derivado de pBS contendo o elemento Tnt1 inteiro clonado

\section{pBSX1 = complete Tnt1-94 element \\ - includes some sequences of the target nia2 gene on each side \\ - cloned in XhoI site of PBS(KS+) - insert $5.5 \mathrm{~kb}$}

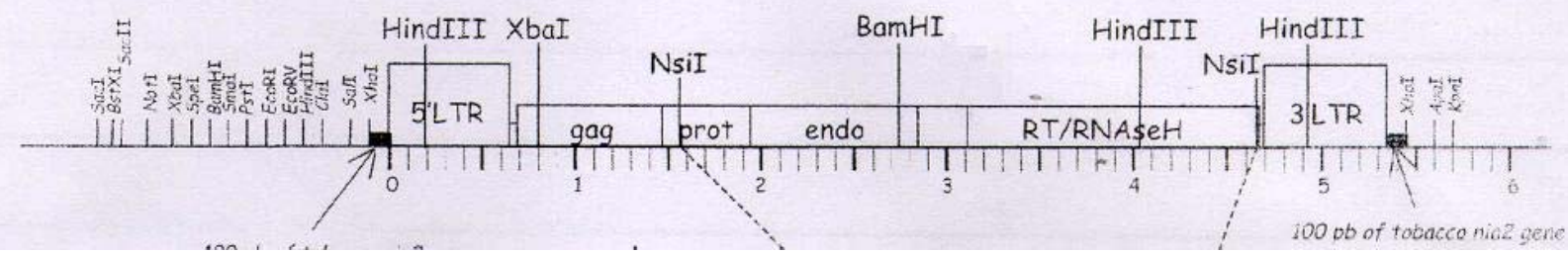

pGEM: $\quad$ pGEM ${ }^{\circledR}-T$ Easy Vector System (Promega), vetor para

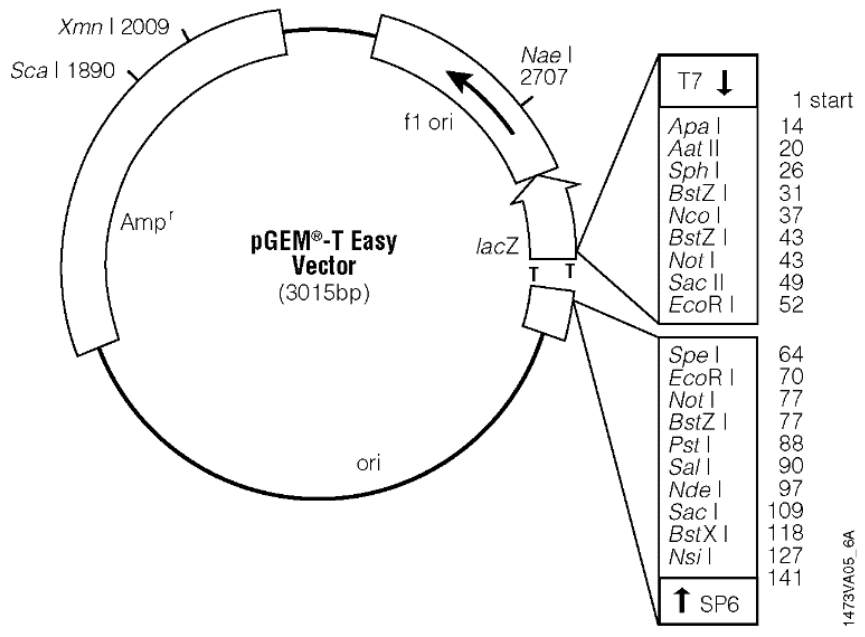


clonagem de fragmentos amplificados por PCR. Possui 3,0 kpb e confere resistência à ampicilina.

pHANNIBAL: com tamanho de $5,8 \mathrm{kpb}$, é um plasmídeo que possibilita a construção de fragmentos de DNA para a indução de RNAi. A construção estará sob controle do promotor $35 \mathrm{~S}$ do vírus do mosaico da couve-flor (CAMv) e conta com a presença de um intron entre a porção senso e antisenso contendo ao final um terminador de transcrição da octopina sintase. O plasmídeo confere resistência à ampicilina. Este plasmídeo foi cedido gentilmente pelo professor doutor Michel Vincentz do Instituto de Biociências da Universidade de Campinas. Possui a propriedade de gerar "hairpins" responsáveis pelo desencadeamento da interferência de RNA devido aos seus sítios de restrição estrategicamente posicionados de modo que de acordo com a combinação desses sítios, o fragmento pode ser inserido em sentido senso ou em sentido anti-senso.

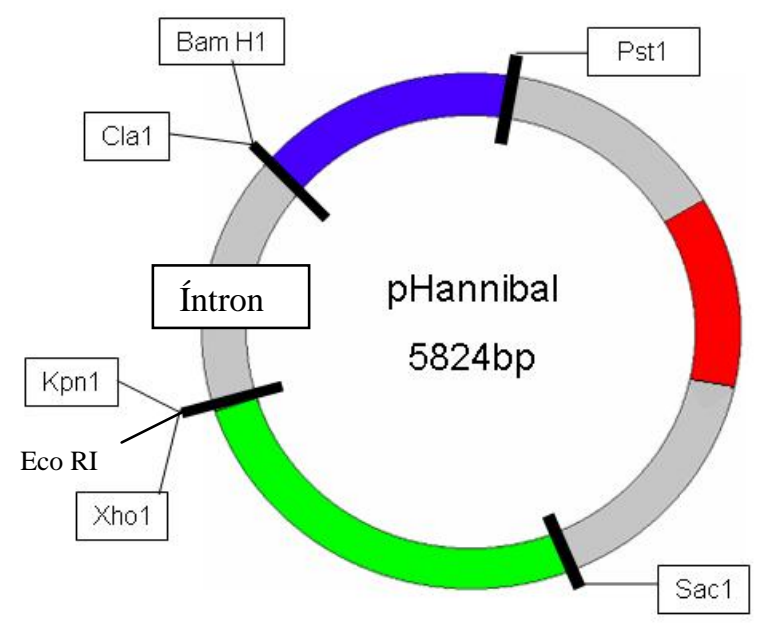

Esquema do plasmídeo HANNIBAL:

Promotor CaMV 35S

Terminador OCS

Resistência a ampicilina 
pCAMBIA1201: plasmídeo binário com origens de replicação em $E$. coli e em Agrobacterium sp. Possui um T-DNA que é transferido para a planta hospedeira quando em Agrobacterium sp.

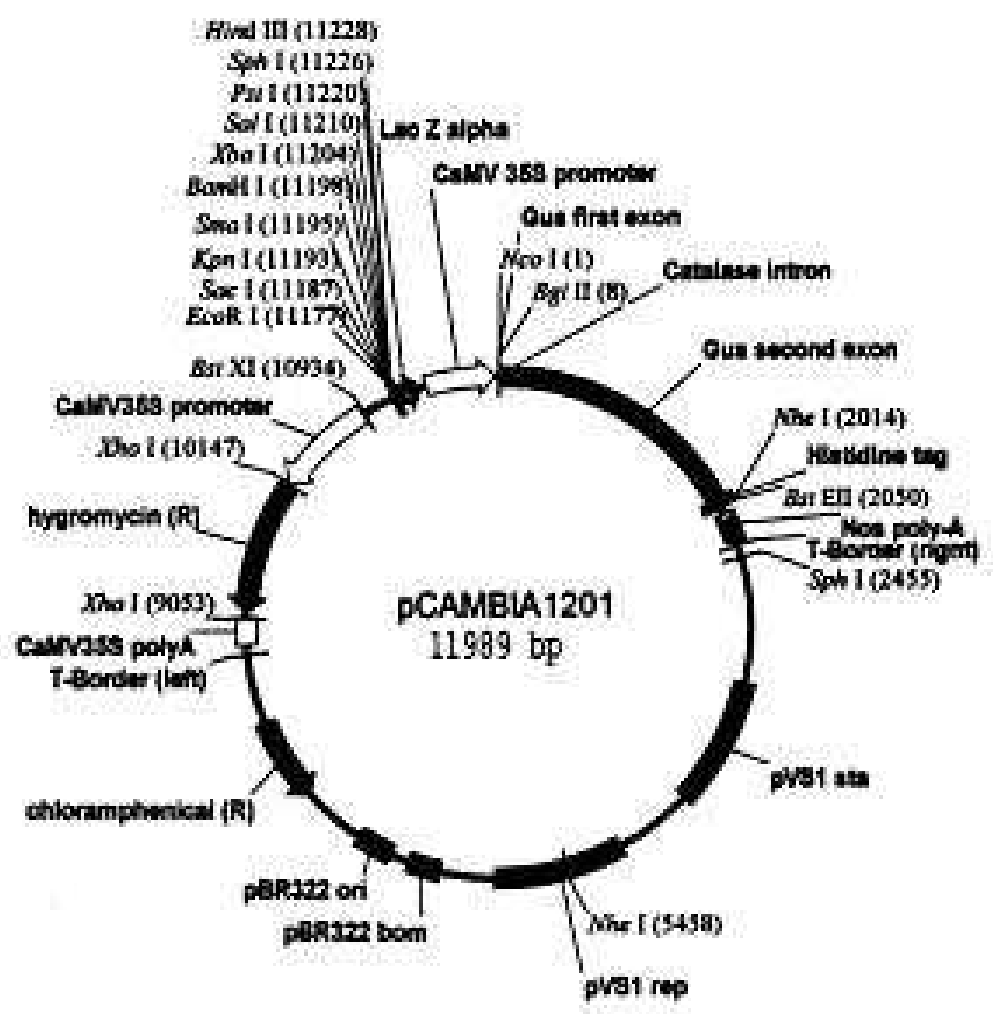

\section{III.7 - Transformação de bactérias competentes por choque térmico}

A metodologia foi baseada em Hanahan (1983). Bactérias competentes foram retiradas do congelador a $-70^{\circ} \mathrm{C}$ e mantidas em gelo durante 15 minutos. Decorrido o tempo, é adicionado o plasmídeo desejado a um volume de $50 \mu \mathrm{l}$ de bactérias. Os tubos Eppendorf contendo a mistura são mantidos em gelo durante 30 minutos sendo em seguida submetidos a choque térmico: 2 minutos a $42^{\circ} \mathrm{C}$ e 3 minutos em gelo. 
São adicionados $400 \mu$ de meio LB ao tubo seguindo-se um período de incubação de 40 minutos a $37^{\circ} \mathrm{C}$ sob agitação. $50 \mu l$ da cultura são inoculados em meio LB sólido contendo o antibiótico de seleção. Com a ajuda de uma alça de Drigalski o espalhamento da cultura sobre o meio sólido é homogeneizado para isolamento de colônias, permanecendo as placas por cerca de 16 horas a $37^{\circ} \mathrm{C}$ para multiplicação de bactérias transformadas.

Toda a manipulação foi realizada em câmara de fluxo de ar laminar, com o uso de material estéril.

\section{III.8 - Preparo de DNA plasmidial}

\section{III.8.1 - Preparo de DNA plasmidial em pequena escala (miniprep)}

\section{Soluções:}

P1:

Tris-HCL

EDTA

RNAse A
$50 \mathrm{mM} \mathrm{pH} \mathrm{8,0}$

$10 \mathrm{mM} \mathrm{pH} 8,0$

$100 \mu \mathrm{g} / \mathrm{ml}$

P2:

$\mathrm{NaOH}$

$200 \mathrm{mM}$

SDS

P3:

Acetato de potássio

$3 \mathrm{M}$

pH 5,5 (ajustado com ácido acético glacial)

\section{Tampão TE}


As substâncias do tampão TE foram dissolvidas em água ultrafiltrada e a solução autoclavada $\left(120^{\circ} \mathrm{C}, 1 \mathrm{~atm}, 15\right.$ minutos $)$.

Uma colônia de bactérias é isolada e colocada em $2 \mathrm{ml}$ de meio LB contendo o antibiótico adequado. Após incubação durante 16 horas a $37^{\circ} \mathrm{C}$, a cultura é transferida para tubos Eppendorf e centrifugada durante pelo menos 60 segundos (todas as centrifugações foram realizadas em centrífuga refrigerada Hettich universal 30RF, rotor angular 1412) a 14000 rpm e seu sobrenadante descartado. As bactérias então são ressuspendidas em $150 \mu \mathrm{l}$ de solução P1, utilizando-se o agitador de tubos. Após a ressuspensão, são adicionados $150 \mu$ l de solução P2 e o tubo é agitado suavemente por inversão e incubado a temperatura ambiente por 5 minutos. Adicionam-se $150 \mu \mathrm{l}$ de P3 e o tubo é novamente agitado por inversão suave logo após a adição da solução. Centrifuga-se a $14000 \mathrm{rpm}$ durante 20 minutos a $4^{\circ} \mathrm{C}$ e o sobrenadante é coletado e transferido para novo tubo. São adicionados $400 \mu l$ de isopropanol e centrifuga-se a $14000 \mathrm{rpm}$ durante 10 minutos à temperatura ambiente. O precipitado é lavado com álcool etílico $70 \%$ e centrifugado a $14000 \mathrm{rpm}$ durante 5 minutos a $4^{\circ} \mathrm{C}$. Depois de seco ao ar o DNA é ressuspendido em 20-30 $\mu$ le tampão TE $1 \mathrm{X}$ ou água microfiltrada. Rendimento médio é de $200 \mathrm{ng} / \mu \mathrm{l}$.

\section{III.8.2 - Extração de DNA plasmidial em média escala (midiprep)}

Para a extração foi utilizado o kit do fabricante Quiagen (Quiafilter Plasmid Midi Kit. - Cat № 12243) seguindo-se protocolo do fabricante. O 
rendimento médio foi de $1 \mu \mathrm{g} / \mu \mathrm{l}$.

\section{III.9 - Manipulação de DNA}

\section{III.9.1 - Hidrólise de DNA com Endonucleases de Restrição}

Para ensaios de hidrólise de DNA foi usada uma unidade de enzima de restrição para cada micrograma de DNA plasmidial. As condições de reação foram determinadas de acordo com as indicações do fabricante das enzimas.

As enzimas utilizadas foram: Bam $\mathrm{HI}$ (fornecida pela Promega) Cla I, Sac I, Pst I (fornecidas pela Fermentas), Xho I, Eco RI (fornecidas pela Pharmacia) e Kpn I (fornecida pela Invitrogen).

\section{III.9.2 - Purificação de DNA}

Para a purificação de DNA provindos de digestão, foi utilizado o kit de purificação por colunas PerfectPrep Gel (cat. N ${ }^{0}$ 0032007.740), do fabricante Eppendorf e o Kit GFX (Promega)

\section{III.9.3 - Ligação de fragmentos de DNA}

Para os ensaios de ligação, realizados a temperatura de $22^{\circ} \mathrm{C}$ por 8 horas, duas proporções entre inserto e vetor foram utilizadas seguindo a relação:

quantidade de vetor $x$ tamanho do fragmento $\times 10^{-3} \times 3$ ou 5 
As reações foram realizadas em condições determinadas pelo fabricante da enzima (Fermentas). Fragmentos obtidos de reações de hidrólise e também de PCR foram clonados em pHannibal. A clonagem foi realizada utilizando-se a enzima T4 DNA ligase (Fermentas). Para a reação de ligação, inserto e vetor foram adicionados seguindo a relação descrita acima. À reação foram adicionados $2 \mu \mathrm{l}$ de enzima ligase (Fermentas), $4 \mu \mathrm{l}$ do tampão fornecido com a enzima (400mM Tris- $\mathrm{HCl}, 100 \mathrm{mM} \mathrm{MgCl} 2,100 \mathrm{mM}$ DTT e 5mM ATP), 20ng de vetor, inserto na quantidade definida pela relação e água para completar um volume final de $20 \mu l$.

\section{III.9.4 - Eletroforese em gel de agarose}

Tampão TBE 10x

$\begin{array}{ll}\text { Tris } & 0,9 \mathrm{M} \\ \text { Ácido bórico } & 0,9 \mathrm{M} \\ \text { EDTA } & 20 \mathrm{mM}\end{array}$

As substâncias foram dissolvidas em água destilada e a solução foi esterilizada em autoclave $\left(120^{\circ} \mathrm{C}, 1 \mathrm{~atm}, 15\right.$ minutos $)$.

Todas as hidrólises realizadas com enzimas de restrição foram confirmadas em gel de agarose de 0,8 a $1 \%$. O gel era submetido a voltagens que variaram entre 20 a 70 volts e as corridas foram realizadas por períodos de 30 a 120 minutos dependendo da voltagem e do tamanho do fragmento. Todas as migrações foram realizadas em tampão TBE 0,5x. 
Meio SOC

Triptona

$20 \mathrm{~g} / \mathrm{l}$

Extrato de levedura

$5 \mathrm{~g} / \mathrm{l}$

$\mathrm{NaCl}$

$0,5 \mathrm{~g} / \mathrm{l}$

$\mathrm{KCl}$

$0,185 \mathrm{~g} / \mathrm{l}$

$\mathrm{MgCl}_{2}$

$4,35 \mathrm{~g} / \mathrm{l}$

$\mathrm{MgSO}_{4}$

$4,8 \mathrm{~g} / \mathrm{l}$

Glicose

$3,6 \mathrm{~g} / \mathrm{l}$

\section{HEPES/KOH}

Hepes

$23,82 \mathrm{~g} / \mathrm{l}$

O sal é dissolvido em água destilada e o pH é ajustado com $\mathrm{KOH}$ para 7,0. A solução é filtrada em filtro Millipore $(40 \mu \mathrm{m})$.

Com uma alça de platina, foi coletada uma amostra de células da linhagem desejada de Agrobacterium e transferida para $10 \mathrm{ml}$ de meio AT com os antibióticos apropriados. Foi incubado a $28^{\circ} \mathrm{C}$ com agitação (100 a $150 \mathrm{rpm})$, por 12 a 16 horas. Após foi transferido $1,5 \mathrm{ml}$ para cada tubo de microcentrífuga. Centrifugou-se a 12000rpm por 1 minuto. Foi ressuspendido delicadamente as células em $0,5 \mathrm{ml}$ de $\mathrm{HEPES} / \mathrm{KOH} 1 \mathrm{mM}$, mantido a $4^{\circ} \mathrm{C}$. Centrifugar a 12000rpm por 1 minuto. Repetiu-se a lavagem com HEPES/KOH por duas vezes e foi ressuspendido delicadamente as células em $0,5 \mathrm{ml}$ de glicerol $10 \%$, mantido a $4^{\circ} \mathrm{C}$. Centrifugou-se por 1 minuto a 12000rpm. Ressuspendeu-se delicadamente as células em $20 \mu \mathrm{l}$ de glicerol $10 \%\left(4^{\circ} \mathrm{C}\right)$ e juntou-se o conteúdo de dois tubos em um. Foi adicionado $1 \mu \mathrm{g}$ de DNA plasmidial, misturado delicadamente e incubado o tubo no gelo por 2 minutos. Transferiu-se a suspensão para a cubeta de eletroporação que foi mantida em gelo. Posicionou-se a cubeta no eletroporador e foi aplicado o pulso. Imediatamente após o pulso, adicionou-se $1 \mathrm{ml}$ de meio SOC e foi 
transferida a solução de células para um tubo de microcentrífuga e incubada a $28^{\circ} \mathrm{C}$ por 4 a 6 horas. Foi plaqueado $100 \mu$ da suspensão de células em meio AT contendo os antibióticos apropriados e incubado a $28^{\circ} \mathrm{C}$ até o aparecimento de colônias isoladas (48 a 72 horas).

\section{III.11 - Transformação de discos foliares por co-cultura}

Com uma alça de platina, foi transferido uma amostra de células de Agrobacterium para $5 \mathrm{ml}$ de meio AT líquido acrescido dos antibióticos adequados. As bactérias foram cultivadas em agitador orbital por aproximadamente 16 horas, a uma frequência de agitação entre 100 e 150 rpm e a uma temperatura de $28^{\circ} \mathrm{C}$, até que a cultura atingisse a fase exponencial de crescimento. Determinou-se a absorbância a 600nm da suspensão bacteriana por leitura em espectrofotômetro. A cultura se encontrava em fase exponencial de crescimento; entre 0,5 e 1. Foi transferido $1 \mathrm{ml}$ da suspensão bacteriana para um tubo de centrífuga estéril e centrifugada a suspensão em microcentrífuga a 5000rpm durante 5 minutos. Descartou-se o sobrenadante e foi ressuspendida as células em $1 \mathrm{ml}$ de $\mathrm{NaCl}$ 0,85\%. As bactérias foram mantidas em temperatura ambiente.

Foi retirada as folhas de fumo microropagadas in vitro (cinco a seis semanas de idade) e cortadas em pedaços com material apropriado. As folhas foram cortadas sob papel filtro estéril, embebido em água ou meio MS30 líquido. Evitou-se áreas cloróticas, necrosadas ou que apresentavam nervuras primárias. Os fragmentos foliares cortadosforam transferidos imediatamente para $20 \mathrm{ml}$ de meio MS líquido em placa de petri. $200 \mu l$ da suspensão bacteriana foi adicionada ao meio MS30 e Agitou-se delicadamente a placa para misturar a suspensão ao meio. As placas foram seladas com filme de PVC e incubadas no escuro durante 48 horas a uma temperatura de $28^{\circ} \mathrm{C}$. 
Decorrido o período de co-cultura, foram lavados os fragmentos foliares pelo menos duas vezes em meio MS30 líquido e secados em papel filtro. Os explantes foram inoculados em meio MS sólido contendo 6BA (1 mg/L) para indução de brotos, cefotaxime (500 mg/L) para evitar o crescimento de bactéria remanescentes e o antibiótico apropriado para seleção das células transformadas. Aproximadamente 10 explantes foram alocados por placa com a face adaxial da folha em contato com o meio. As placas foram seladas com filme de PVC e incubadas em sala de cultura com um fotoperíodo de 16 horas a uma temperatura de 25 a $28^{\circ} \mathrm{C}$.

Após três semanas em placa, notou-se o crescimento de calos que foram separados do disco para preservar eventos de transformação diferentes. Estes calos foram passados para outra placa contendo o meio citado anteriormente. Identificou-se os brotos maiores de $0,7 \mathrm{~cm}$ que foram surgindo e foram passados para magenta com meio MS30 sólido acrescido de cefotaxime $(250 \mathrm{mg} / \mathrm{L})$ e antibiótico apropriado. Foi mantido os brotos nesse meio até desenvolvimento completo de raízes.

\section{III.12 - Ensaio histoquímico}

Tampão de reação

\begin{tabular}{ll}
$\mathrm{NaH}_{2} \mathrm{PO}_{4} \cdot \mathrm{H}_{2} \mathrm{O}$ & $100 \mathrm{mM}$ \\
$\mathrm{K}_{4} \mathrm{Fe}(\mathrm{CN})_{6} \cdot 3 \mathrm{H}_{2} \mathrm{O}$ & $0,5 \mathrm{mM}$ \\
$\mathrm{Na}_{2} \mathrm{EDTA} .2 \mathrm{H}_{2} \mathrm{O}$ & $10 \mathrm{mM}$ \\
Triton $^{\circledR} \mathrm{X}-100$ & \multicolumn{1}{c}{$0,1 \%$} \\
X-Gluc & $1 \mathrm{mM}$
\end{tabular}

As substâncias são diluídas em água destilada. $\mathrm{O}$ pH é ajustado para 7,0 com $\mathrm{NaOH}$ e a solução é esterilizada por filtração (filtro Millipore $40 \mu \mathrm{m})$. 
Incubou-se o tecido no tampão de reação em volume suficiente para cobrir a amostra. Foi Vedado o recipiente para evitar a evaporação do tampão e a amostra foi encubada no escuro a $37^{\circ} \mathrm{C}$ por um período de 16 horas. Após decorrido o período, foi retirado o tampão de reação e adicionado etanol $70 \%$ para interromper a reação e retirar a clorofila permitindo uma melhor visualização da coloração azul. Após 16 a 24 horas, as amostras foram lavadas em água destilada e transferidas para glicerol $50 \%$.

III.13 - Análise da expressão de Tnt1 e Tto1 em Nicotiana tabacum por Northern Blot

\section{Soluções}

MOPS 10x

MOPS

$0,2 \mathrm{M} \mathrm{pH}$

7,0

Acetato de sódio

$0,5 \mathrm{M} \mathrm{pH} 7,0$

EDTA

$0,01 \mathrm{M}$

\section{Tampão MOPS 10x}

$\begin{array}{ll}\text { MOPS } & 0,4 \mathrm{M} \mathrm{pH} 7,0 \\ \text { NaOAc } & 0,1 \mathrm{M} \mathrm{pH7,0} \\ \text { EDTA } & 1 \mathrm{mM}\end{array}$

Tampão de pré hibridação

SDS

EDTA

8,0 Tampão fosfato
$7 \%$,

$1 \mathrm{mM} \mathrm{pH}$

$0,5 \mathrm{M} \mathrm{pH} 7,4$ 


\section{III.13.1 - Preparo da Membrana}

RNA total de plantas transformadas com as construções realizadas e selvagem foi extraído conforme descreve o item acima. Alíquotas dos diferentes RNAs contendo $5 \mu \mathrm{g}$ foram desnaturadas, por $15 \mathrm{~min}$ a $65^{\circ} \mathrm{C} \mathrm{em}$ solução contendo MOPS $1 \mathrm{x}$, formaldeido $37 \%(0,82 \mu \mathrm{l}$ por microlitro de amostra) e formamida $(2,28 \mu l$ por microlitro de amostra). Após a adição do tampão de amostra (50\% glicerol, 1mM EDTA, 0,125\% azul de bromofenol, 0,125\% xileno cianol) as amostras de RNA foram fracionadas por eletroforese em gel de agarose $2 \%$, formaldeido $37 \%$ e tampão MOPS1x. A corrida foi realizada em 3 horas. Terminada a corrida, o gel foi lavado 2 a 3 vezes com água, 15 minutos cada lavagem. A seguir, os RNAs foram transferidos para uma membrana de nylon Hybond N (Amersham-Pharmacia) em SSC 10x, por capilaridade. Após a transferência, a membrana foi seca por $2 \mathrm{~h}$ à $80^{\circ} \mathrm{C}$, sendo os RNAs fixados à membrana sob UV a 1 min.

\section{III.13.2 - Preparo da Sonda}

Para a síntese da sonda do elemento Tnt1, utilizamos como molde o próprio elemento contido no vetor pBSX-1 utilizando os iniciadores RT1BamF/RT2Cla-R. Para a sonda do elemnto Tto1, foi realizada uma amplificação do DNA genômico de fumo utilizando-se os iniciadores Tto1-F/Tto1-R que são específicos para amplificação da transcriptase reversa do elemento Tto1. O produto das amplificações foram verificados em gel de agarose $1 \%$ e os DNAs purificados. A purificação do DNA do gel foi feita com o kit GFX® (Promega) .O DNA foi desnaturado à $99^{\circ} \mathrm{C}$ durante $5 \mathrm{~min}$. A sonda foi 
marcada pelo kit Random Primers DNA Labeling System (Invitrogen-181870). Para marcação para ser utilizado como sonda, o DNA desnaturado é colocado na presença de oligo-desoxirribonucleotídeos com seqüências randômicas que servem como iniciadores para a enzima Klenow. O [a$\left.{ }^{32} \mathrm{P}\right] \mathrm{dCTP}$, então, incorporado durante a extensão do iniciador possibilitando a marcação da sonda. Para uma incorporação máxima do radioativo a reação foi deixada durante 3 horas à $37^{\circ} \mathrm{C}$.

\section{III.13.3 - Hibridação, lavagem e exposição da Membrana}

A membrana foi incubada $2 \mathrm{~h}$ à $65^{\circ} \mathrm{C}$ em $30 \mathrm{ml}$ de solução de préhibridação e, a seguir, a sonda radioativa desnaturada com $1 / 3$ do volume de $\mathrm{NaOH} 1 \mathrm{~N}$ por 5 min e neutralizada com 1 volume de tris $1 \mathrm{M}(\mathrm{pH} 8,0)$ foi adicionada à solução permanecendo por $12-36 \mathrm{~h}$ à $65^{\circ} \mathrm{C}$. Após a hibridação, a membrana foi lavada 2 a 3 vezes em solução SSC 10x ( $\mathrm{NaCl}$ 1,5M e Citrato de Sódio $0,15 \mathrm{M}$ ), com 15 min cada lavagem, sendo a primeira lavagem feita à temperatura ambiente e as demais à $65^{\circ} \mathrm{C}$. A membrana foi exposta ao filme (Kodak) por 1 a 5 dias com intensificador à $-80^{\circ} \mathrm{C}$ e depois o filme foi revelado utilizando-se revelador e fixador Kodak. 
IV - RESULTADOS

\section{IV.1 - Análise de domínios}

A comparação das regiões conservadas foram realizadas através da ferramenta BLAST2SEQ no sítio da internet do NCBI. Foram comparadas a sequência de nucleotídeos do domínio da transcriptase reversa dos elementos Tnt1 (número de acesso 20044) e Tto1 (número de acesso1167522). 


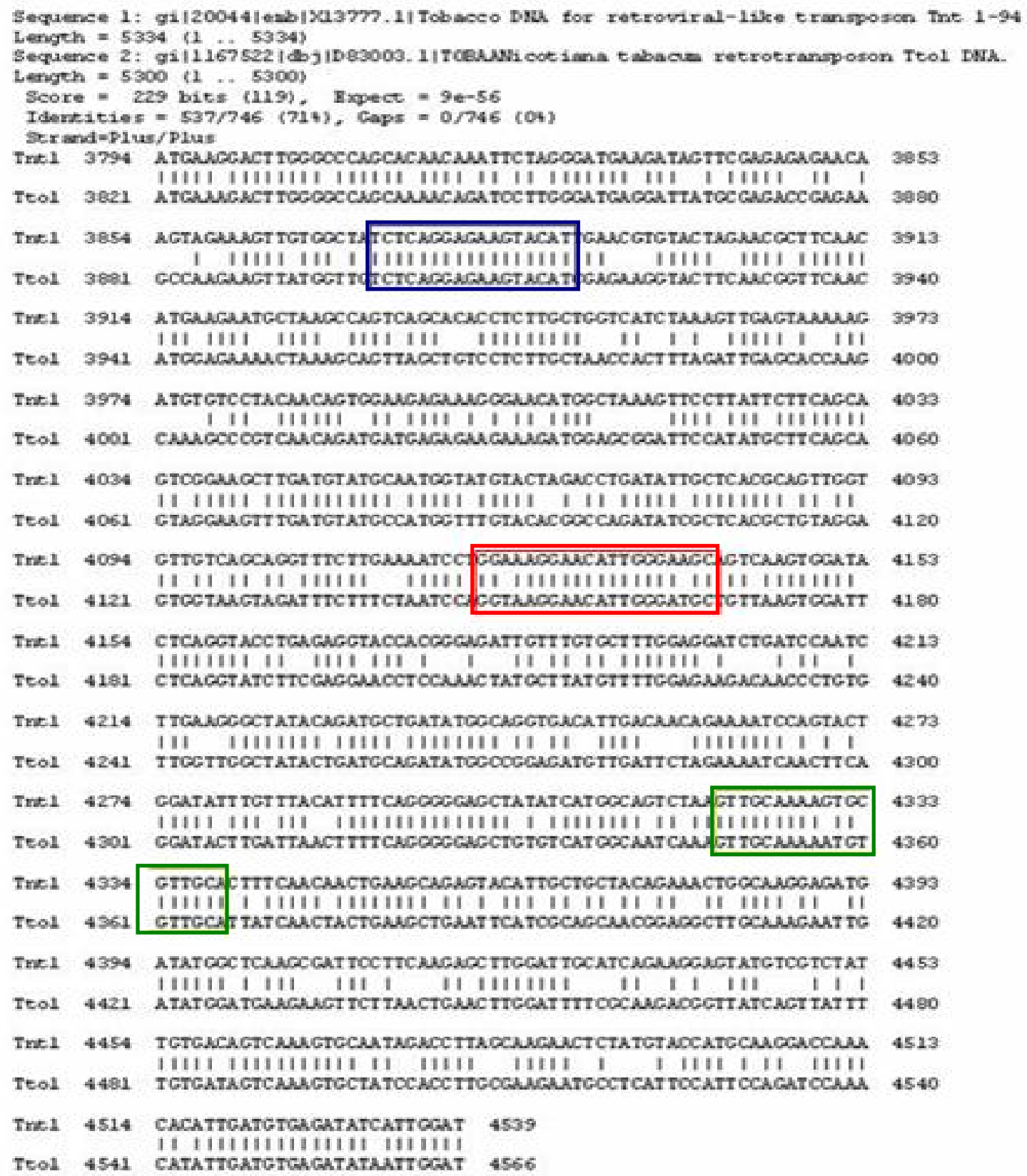

Figura 5: Comparação da sequência de nucleotídeos dos ementos Tnt1 e Tto1 do domínio da transcriptase reversa. Dentro dos retângulos se encontram as regiões escolhidas para desenho de iniciadores para desenvolvimento de construções de interferência.

A análise da figura permite observar que ambos os elementos compartilham de similaridade em nucleotídeo na região que codifica a Transcriptase reversa. Pela figura verifica-se que não há um alinhamento extenso e que as áreas que possuem cem por cento de identidade são curtas, sempre menores que 20 nucleotídeos alinhados. A região da 
transcriptase reversa dos dois elementos possuem uma identidade de setenta e um por cento sendo a região melhor conservada entre ambos os elementos. Em função do conhecimento disponível no momento da execução do presente projeto não era possível afirmar se ocorreria ou não o silenciamento do retroelemento Tto1.

\section{IV.2 - Construções Interferência, Anti-senso e Controle}

\section{IV.2.1 - Amplificação da transcriptase reversa}

Os iniciadores foram desenhados com sítios de restrições nas extremidades de modo a facilitar a clonagem junto ao plasmídeo pHANNIBAL. Para amplificações em sentido senso, os iniciadores utilizados possuem sítios de restrição para as enzimas Xho I e Kpn I, e para amplificações em sentido anti-senso, foram utilizados iniciadores com sítios de restrições para as enzimas Bam $\mathrm{HI}$ e Cla I. Os fragmentos amplificados foram analisados em gel de agarose 1\% como apresentado na figura 6.

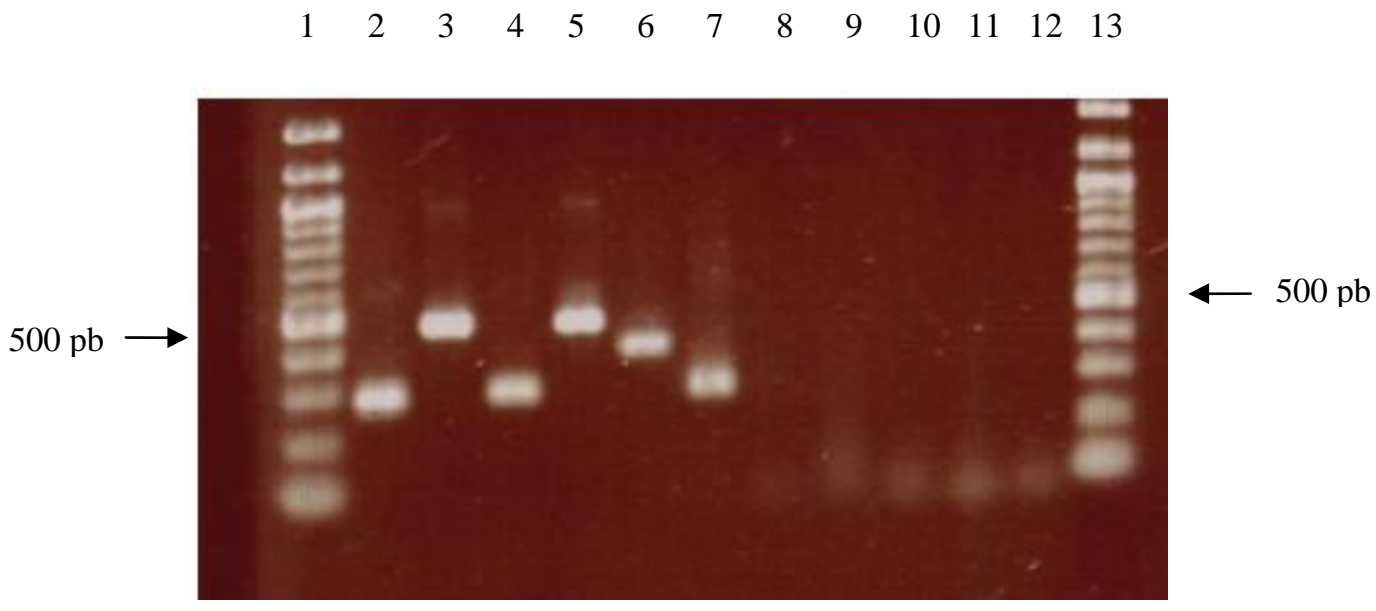

Figura 6: Amplificações de fragmentos para clonagem em plasmídeo pHANNIBAL. 1 - marcador $100 \mathrm{pb} ; 2$ - fragmento menor anti-senso; 3 - fragmento maior antisenso; 4 - fragmento menor senso; 5 - fragmento maior senso; 6 - controle positivo de amplificação; 7 - fragmento menor anti-senso amplificado de DNA genômico de 
tabaco; 8 - controle negativo de fragmento menor anti-senso; 9 - controle negativo de fragmento maior anti-senso; 10 - controle negativo de fragmento menor senso; 11 controle negativo de fragmento maior senso; 13 - marcador $100 \mathrm{pb}$.

Os produtos de PCR foram retirados do gel de agarose e purificados para clonagem no vetor pGEM-T-Easy. A clonagem foi feita de acordo com as especificações do fabricante. Os produtos de ligação foram usados para transformação de bactérias E. coli, que foram selecionadas por resistência ao antibiótico ampicilina, e pela diferença de coloração conferida pelo gene da $\beta$ galactosidase presentes no vetor pGEM inserido.

Foram selecionadas duas colônias de cada um dos quatro vetores para que fossem propagadas e por mini preparação de plasmídeo, o vetor inserido foi extraído. Após a extração, foi realizada a digestão dos vetores utilizando-se os sítios desenhados nos iniciadores sendo os fragmentos inseridos retirados e verificados em gel de agarose 1\%. As colônias que apresentavam os fragmentos esperados foram escolhidas e utilizadas para continuidade do trabalho sendo feito um estoque em glicerol $50 \%$ e mantido a $-70^{0} \mathrm{C}$.

Os quatro fragmentos foram clonados, sequenciados e comparados à transcriptase reversa e todos os fragmentos apresentaram cem por cento de identidade à região do elemento Tnt1. O sequenciamento foi realizado com os iniciadores T7 e SP6, iniciadores desenhados exclusivamente para amplificação do sítio de clonagem do vetor pGEM. A figura 7 exemplifica o sequenciamento e comparação. 
TCTNCCATTATGGACGACCTGCAGGCGGCCGCTAATTCACATAGTGATTCCATCGATACTGCTTCCCAATG TTCCTTTCCAGGATTTTCAAGAAACCTGCT GACAACACCAACTGCGTGAGCAATATCAGGTCTAGTACAT ACCATTGCATACATCAAGCTTCCGACTGCTGAAGAATAAGGAACTTTAGCCATGTTCCCTTTCTCTTCCAC TGTTGTAGGACACATCTTTTTACTCAACTTTAGATGACCAGCAAGAGGTGTGCTGACTGGCTTAGCATTCT TCATGTT GAAGCGTTCTAGTACACGTTCAAT GTACTTCTCCT GAGATGGA TCCCGAATCGAATTCCCGCGG CCGCCA TGGCGGCCGGGAGCA TGCGACGTCGGGCCCAATTCGCCCTAT AGT GAGA TCGT ATTACAATTCA CTGGCCGTCGTTTTACAACGTCGTGACTGGGAAAACCCTGGCGTTACCCAACTTAATCGCCTTGCAGCAC ATCCCCCTTTCGCCAGCTGGCGTAATAGCGAAGA GGCCCGCACCGATCGCCCTTCCCAACAGATTGCGCA GCCT GAAAT GGCGAAT GHACGCGCCCTGTAAHCGGCGCATTTA AGCGCGGC GGHHGTGGTGGTTTACGC HCAHCGTGACCGCTACACTTTGCCAGCGCCCCTAGCGCCCGCHTCCTTTCGCTTHCHTCCCTTHCTTTCCT CHCCHCGNTTCGNCGGCHTTTCCCGHTCAAHCTHTAAATCHGGGGCHTCCCHTTTGGGNTTCCGATTTAG TGCHTTTCHGHNCCTCCTACCCCANA AATTTNATAAGGGGGATGGTTCCCGANTHGGCCCAHCCCCTTGA TAAAHGTTTHTCGCCCTTTGNAGTHGAATCACCTTCTTTAAHAH GHAHCT GHTCCHATHGAAAACHCACC TTHCGGTTTTTTTGNATTAAHGGA TTTGY

1A:RT1BAM - F / RT2CLA-R T7

TGGCGGCCGCGGGAATTCGATTCGGGA TCCATCTCAGGAGAA GTACATTGAACGTGTACTAGAACGCTTC AACATGAAGA ATGCTAAGCCAGTCAGCACACCTCTTGCTGGTCATCTAAAGTTGAGTAAAA AGATGTGTC CTACAACAGTGGAAGAGAAAGGGAACA TGGCTAAAGTTCCTTATTCTTCAGCAGTCGGAAGCTTGATGTA TGCAATGGTAT GTACTAGACCTGATATTGCTCACGCAGTTGGT GTT GTCAGCAGGTTTCTTGAAAATCCTG GAAAGGAACATTGGGAAGCA GTATCGATGGAATCACTAGTGAATTCGCGGCCGCCTGCAGGTCGACCAT ATGGGAGA GCTCCCAACGCGTTGGATGCATAGCTTGAGTATTCTATAGTGTCACCTAAATAGCTTGGCGT AATCATGGTCATAGCTGTTTCCTGTGTGAAATTGTTATCCGCTCACAATTCCACACAACATACGAGCCGG AAGCATAAAGTGTAAAGCCTGGGGTGCCTAATGAGTGAGCTAACTCACATTAATTGCGTTGCGCTCACTG CCCGCTTTCCAGTCGGGGAAHCCTGTCGTGCCAGCTGCHATTAATTGAATCHGCCCAACGCGCGGGGAA G AGGCGGTTTGCGTATTGGGCGCTCTTCCGCTTCCTCHCTCACTGACTCGCTGCGCTCGNTCGTTCGGCTGC NGCGA GCGNTATCAHCTCACTCAAAGCCGGTAATACGGTTATCCCAGAATCAGGGHATAACCCAGAAAA ACHTGTGAACAAAAGGCCACAAAAGNCCA GAACCTAAAAGGCCCGTTGCT GHGTTTTCANAGNTCCGC CCCCTGAAAHCATCCAAA ATCGAHTTCANTHNAAAGHGNGA ACCCGCCGGATHNAA AAACCHGGGTTCC CCTGGHACCCHCGN

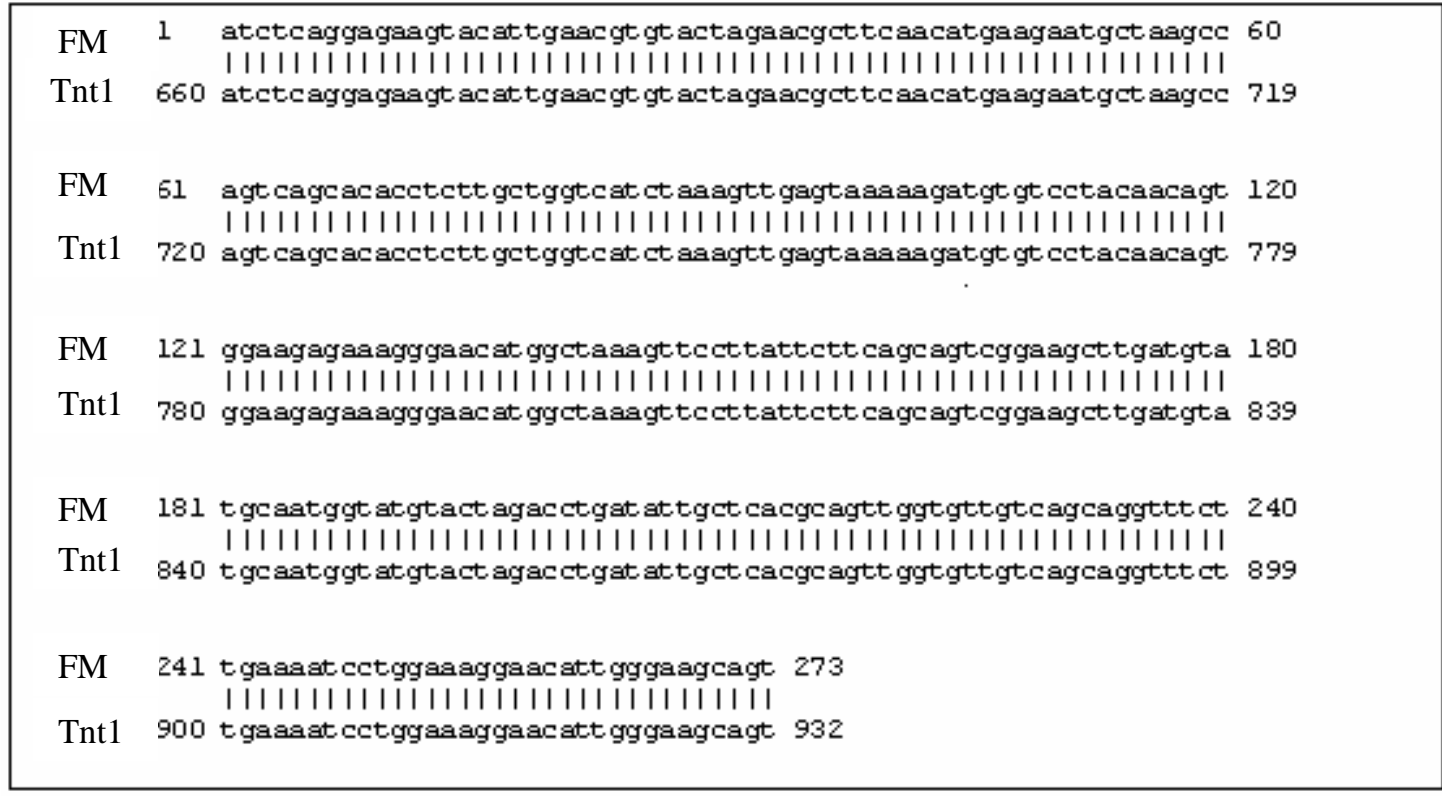

Figura 7: Resultados do sequenciamento. (A) Sequenciamento do fragmento menor com orientação anti-senso clonado em vetor pGEM e sequenciado com os iniciadores T7 e SP6. Estão localizados na figura sítios de restrição para as enzimas Bam HI e Cla I assim como as bases do fragmento clonado (verde). (B) Comparação entre sequência do fragmento menor (FM) com orientação anti-senso e a sequência da transcriptase reversa do elemento Tnt1. 


\section{IV.2.2 - Construção anti-senso}

Com as comparações realizadas e confirmações da sequências, os fragmentos clonados no vetor pGEM foram retirados utilizando-se sítios de restrição desenhados nas extremidades dos fragmentos. As primeiras construções realizadas foram as clonagens dos fragmentos menor e maior em orientação anti-senso no vetor pHANNIBAL que foram retirados do vetor pGEM utilizando os sítios das enzimas Bam HI e Cla I. Após a hidrólise dupla, foi verificado em gel de agarose, a liberação dos fragmentos de 273pares de base e 470 pares de base, respectivamente. Depois da visualização dos fragmentos, estes foram retirados do gel de agarose e purificados para ligação em vetor pHANNIBAL. Este vetor foi linearizado por dupla digestão com as endonucleases Bam HI e Cla I e verificado em gel de agarose $0,8 \%$. Após confirmada a linearização, foram realizadas as ligações de acordo com ítem III.9.3 e os produtos de ligação foram utilizados para transformação de bactérias E. coli por choque térmico. Através de seleção ao antibiótico ampicilina e por coloração do gene da $\beta$-galactosidase, oito colônias de cada uma das ligações foram selecionadas e propagadas. Destas colônias foram realizadas mini preparação de plasmídeos e o material genético extraído foi digerido com as enzimas Bam HI e Cla I para confirmação das ligações. A estratégia utilizada foi a digestão do material genético das colônias selecionadas com as mesmas enzimas utilizadas na clonagem dos fragmentos no vetor pHANNIBAL. Se a ligação fosse bem sucedida, com a dupla digestão, os fragmentos poderiam ser visualisados em gel de agarose e a confirmação de que a parte anti-senso da construção para desencadeameto da interferência de RNA e as construção que gerarão a inibição por anti-senso estariam prontas. Das oito colônias de cada uma das 
transformações realizadas, duas colônias de cada transformação que continham o inserto foram escolhidas para estoque e uma colônia de cada trasnformação foram escolhidas para continuidade do trabalho. A figura 8 representa a digestão do material genético extraído das colônias transformadas pelos produtos de ligação escolhidas para estoque.

A

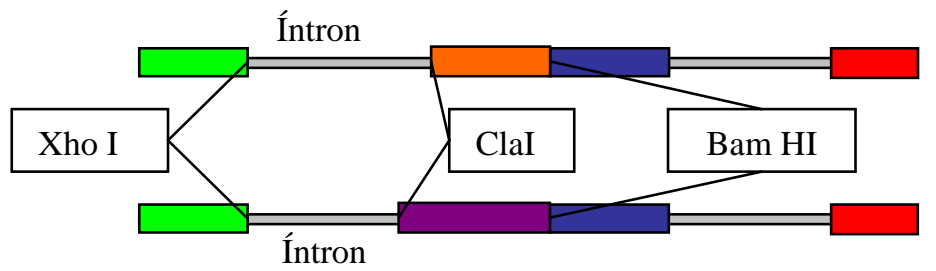

Resistência a

ampicilina

Promotor

Terminador

Fragmento menor

Fragmento maior

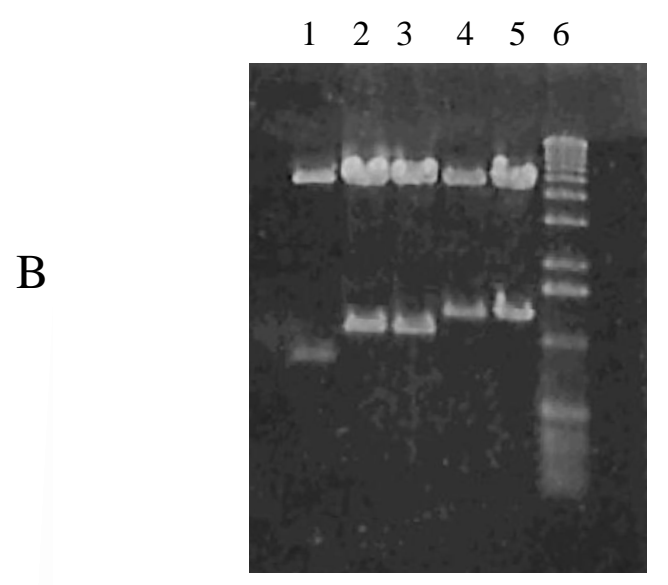

Figura 8: (A) Representação da digestão do plasmídeo pHANNIBAL pelas endonucleases Bam HI e XhoI. O fragmento foi clonado em Bam HI e Cla I, mas a digestão realizada com as endonucleases Bam HI e Xho I possibilitaria a visualização do tamananho do fragmento contendo o íntron e a sequência clonada para podermos descartar a possibilidade de que mais de uma cópia fosse inserida no vetor. (B) Gel de agarose representando as digestões do plasmídeo pHANNIBAL com os fragmentos maior e menor clonados.

1 - Plasmídeo pHANNIBAL digerido; 2 e 3- Plasmídeo pHANNIBAL mais fragmento menor digerido; 4 e 5 - Plasmídeo pHANNIBAL mais fragmento maior digerido; 6 - Ladder $1 \mathrm{~kb}$.

Pela figura $8 \mathrm{~B}$ podemos visualizar que as clonagens dos fragmentos retirados do vetor pGEM foram realizadas com sucesso. O íntron presente no vetor pHANNIBAL possui 980 pares de base representado na figura pelo 
número 1. As digestões do vetor com o fragmento menor clonado possui 1253 pares de base como podemos notar no gel pelo número 2 e 3 e a digestão do vetor com o fragmento maior possui 1450 pares de base representados no gel pelos números 4 e 5 .

$O$ vetor pHANNIBAL com o fragmento menor clonado foi chamado de 273as e com o fragmento maior foi chamado de 470as. Com a parte antisenso pronta, passamos para a parte senso para completar a construção no vetor pHANNIBAL.

\section{IV.2.3 - Construção senso}

Para a clonagem dos fragmentos maior e menor em sentido senso, os sítios para enzima de restrição Xho I e Eco RI foram utilizadas para digestão do fragmento maior (devido a presença de dois sítios Kpn I encontrados internamente no fragmento) e Xho I e Kpn I para o fragmento menor. Primeiramente, foram utilizados os fragmentos clonados em vetor pGEM de nossos estoques para a construção. Os fragmentos menor e maior para serem clonados em vetor pHANNIBAL em sentido senso foram retirados do vetor pGEM pelas enzimas anteriormente citadas e separados por gel de agarose. Os fragmentos foram purificados com o kit PerfectPrep Gel da Eppendorf. Os vetores 273as e 470as também foram digeridos com as enzimas Xho I e Kpn I; e Xho I e Eco RI, respectivamente. Foram então elaborados experimentos de ligação da mesma maneira como na clonagem dos fragmentos de sentido anti-senso. O produto de ligação foi utilizado para transformação de bactérias E. coli e por seleção ao antibiótico ampicilina e pela coloração proveniente do gene Lac Z, as colônias foram escolhidas.

A ligação do produto de amplificação com o vetor 273as digerido seguiu o 
mesmo protocolo das ligações anteriores. O produto da ligação foi transferido para células de E. coli que por resistência e coloração foram selecionadas. No total foram selecionadas oito colônias para propagação e mini preparação de plasmídeos. O material genético foi digerido com as enzimas Xho I e Kpn I para liberação do fragmento recém clonado e duas colônias apresentaram estes fragmentos. Estas colônias foram colocadas em nosso estoque uma delas foi escolhida para continuidade do nosso trabalho sendo chamadas de 273sas. A digestão do vetor 273sas está representada na figura 9.

$\begin{array}{lllll}1 & 2 & 3 & 4 & 5\end{array}$

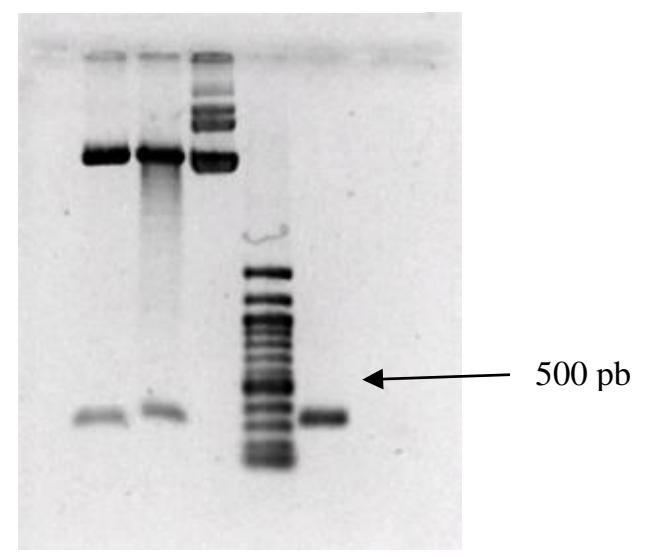

Figura 9: Digestão do vetor 273sas com as duplas de enzimas Bam HI e Cla I, e Xho I e Kpn I. 1 - 273sas digerido com Bam HI e Cla I; 2 - 273sas digerido com Xho I e Kpn I; 3 - 273sas não digerido;4 - ladder 100 pb; 5 - fragmento menor

Agora com os vetores 273as, 273sas e 470as prontos, o próximo passo tomado foi a clonagem das construções realizadas no vetor pCAMBIA, um vetor binário com origens de replicação em E. coli e Agrobacterium tumefaciens. Este último servirá como vetor de transformação de plantas de fumo.

\section{IV.3 - Clonagem em vetor pCAMBIA}

Para obtenção dos plasmídeos binários que serão utilizados no momento da transformação de plantas de fumo através de Agrobacterium, foi 
necessária a transferência dos cassetes gênicos do vetor pHANNIBAL para pCAMBIA 1201 através de ensaios de digestão e de ligação com os vetores 273sas, pCAMBIA 1201 e 470as. Primeiramente, os vetores foram digeridos com as enzimas Sac I e Pst I e as digestões foram confirmadas em gel de agarose. O passo seguinte foi a ligação entre os fragmentos provindos dos vetores 271sas e 470as com o vetor pCAMBIA 1201.

Os produtos de ligação foram utilizados para transformação de células de E. coli que foram selecionadas por resistência a cloranfenicol presente no vetor pCAMBIA e por coloração devido ao gene que codifica a enzima betagalactosidase. No total foram escolhidas 24 colônias de cada ligação que foram propagadas e crescidas em meio líquido para extração de DNA em pequena escala. Os plasmídeos foram digeridos com as enzimas Sac I e Pst I para verificação do inserto e separados em gel de agarose $1 \%$.

O vetor que possui a construção 273sas clonado em pCAMBIA recebeu o nome de pBKTnt1RT273ri e o vetor que possui a construção 470as recebu o nome de pBKTnt1RT470as. 


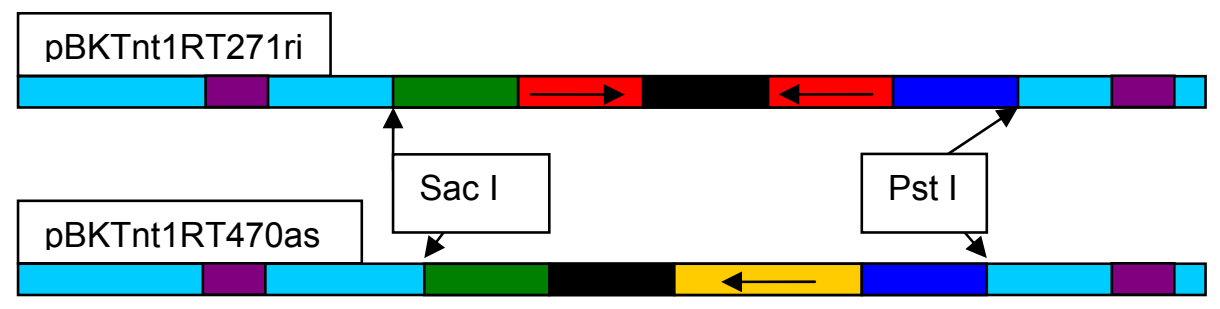

Promotor 35S

Fragmento 271pb Íntron

Fragmento 470pb

Terminador OCS

Vetor CAMBIA

Bordas R e L

A

$12230456 \quad 6 \quad 7 \quad 8 \quad 91011121314$

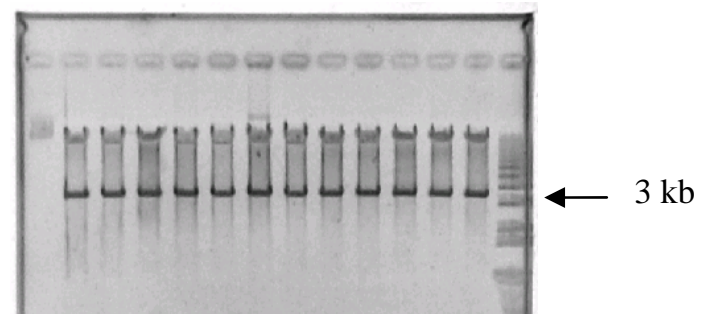

1516171819202122232425262728

B

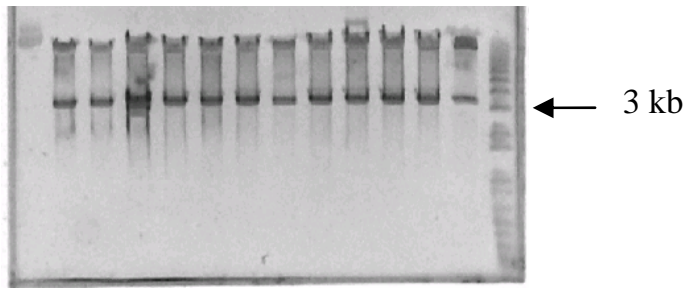

$1 \quad 2 \quad 3 \quad 4 \quad 5 \quad 6 \quad 7 \quad 8 \quad 91011121314$

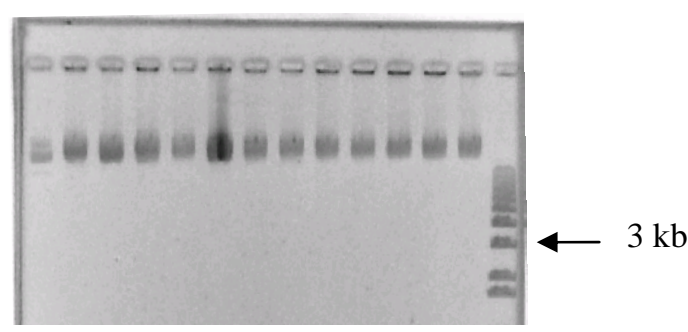

1516171819202122232425262728

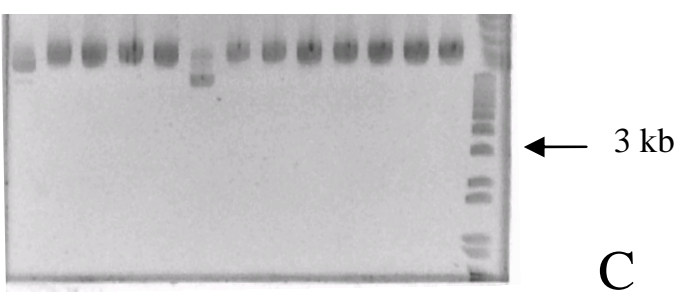

Figura 10: (A) Representação de digestão dos plasmídeos pBKTnt1RT271ri e pBKTnt1RT470as com as enzimas SacI e PstI. (B) Digestões da construção pBKTnt1RT271 provindas de diferentes colônias transformadas. 1 e 15 pBKTnt1RT271ri não digerido; 2 a13 e 16 a 27 - diferentes colônias digeridas; 14 e 28 - Ladder 1kb. (C) Digestões da construção pBKTnt1RT470as provindas de diferentes colônias. 1 e 15 - pBKTnt1RT470as não digerido; 2 a 13 e 16 a 23 diferentes colônias digeridas; 14 e 18 - Ladder $1 \mathrm{~kb}$.

De acordo com a figura 10, todas as colônias provindas do vetor 273sas possuem o inserto esperado de $3502 \mathrm{pb}$, Nova digestão foi realizada após purificação do DNA extraído e conseguimos visualisar que a maioria das colônias continham o inserto desejado sendo escolhidas três da transformação com pCAMBIA/273sas e quatro da transformação pCAMBIA/470as como mostrado na figura 11. 
A

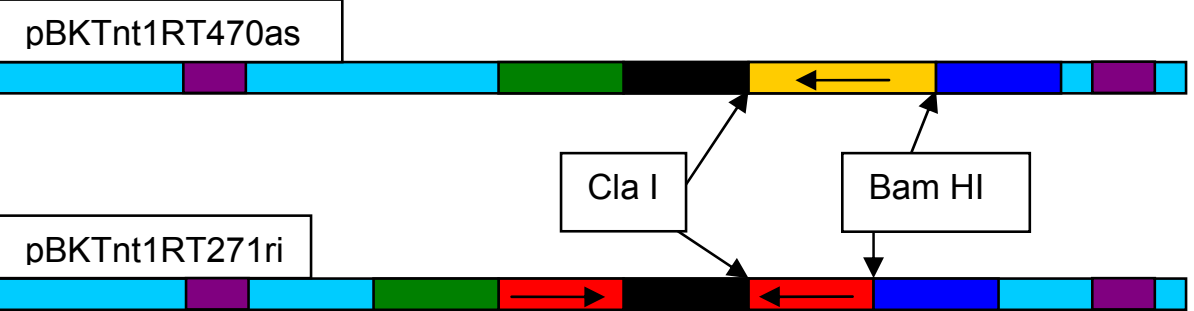

Promotor 35S

Íntron

Fragmento

Terminador

OCS

Vetor CAMBIA

Bordas R e L

B

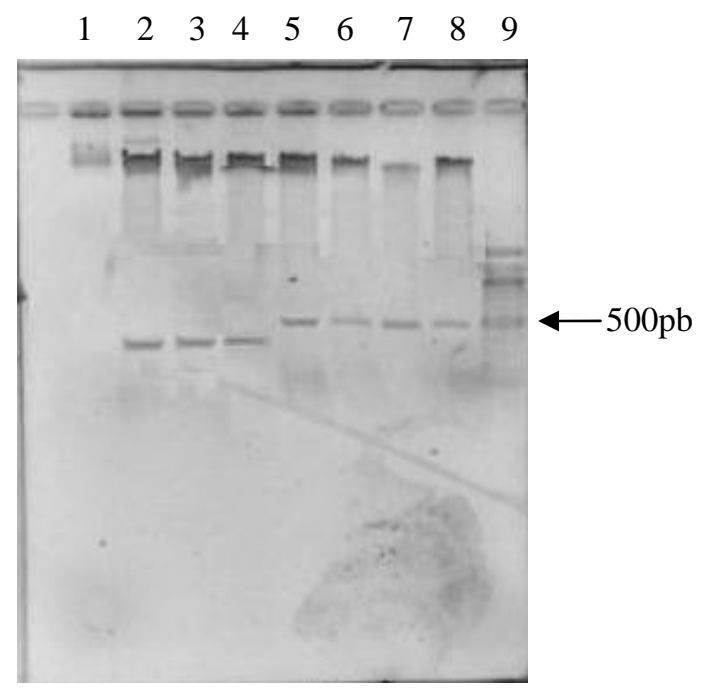

Figura 11: (A) Representação esquemática dos vetores pBKTnt1RT470as e pBKTnt1RT271ri com a localização dos sítios de restrição das enzimas ClaI e PstI . (B) Gel de eletroforese de digestões com as enzimas Bam HI e Cla I para diferentes colônias contendo os plasmídeos pBKTnt1RT470as e pBKTnt1RT273ri. 1 pBKTnt1RT470as não digerido; 2,3 e 4 - diferentes colônias contendo o plasmídeo pBKTnt1RT273ri; 5 a 8 - diferentes colônias contendo o plasmídeo pBKTnt1RT470as; 9 - Ladder 100pb.

Destas colônias, duas de cada transformação foram escolhidas para estoque sendo que uma foi escolhida para continuidade do trabalho.

\section{IV.4 - Construção do vetor pBKTnt1RT273asm}

A construção anti-senso menor foi desenvolvida seguindo-se os métodos já descritos através de hidrólises e ligações por sítios de restrições coesivos. Esta construção foi realizada para podermos comparar os 
resultados do vetor pBKTnt1RT470as com outro que teria uma sequência menor. Para realização desta nova construção, foi utilizado um vetor intermediário que já havia sido descrito e que estava pronto em plasmídeo pHANNIBAL, o vetor 273as. Esta construção foi hidrolisada com as enzimas Sac I e Pst I assim como o plasmídeo pCAMBIA 1201. Os dois produtos foram ligados e o produto da ligação foi transferido para E.coli. Uma extração de DNA plasmidial foi realizada e através de eletroporação, a construção foi clonada em Agrobacterium tumefaciens. Através de gel de agarose a ligação foi confirmada como mostrada na figura 12.

A

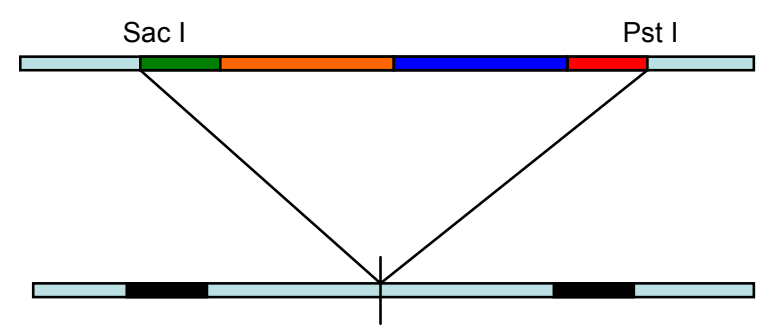

Promotor 35S

Fragmento de 271 pares de base Íntron

Terminador OCS

Bordas

1234

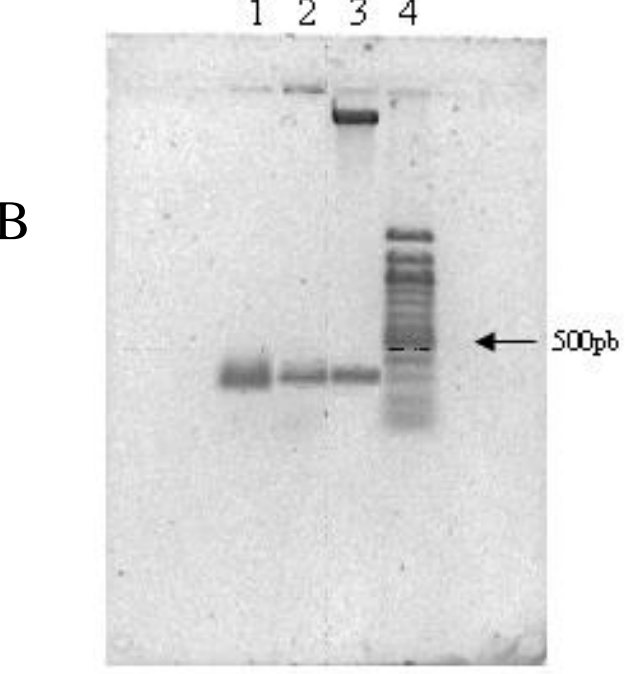

Figura 12: (A) Representação das digestões realizadas para clonagem do vetor 273as para o vetor pCAMBIA.(B) Gel de confirmação de inserto em Agrobacterium tumefaciens. 1 - PCR de E.coli DH10Bcontendo a construção 273as com iniciadores RT1BamHI - F / RT2ClaI - R que amplificam o fragmento de 273pb (controle 
positivo); 2 - PCR da colônia de Agrobacterium LBA4404 transformada com a construção 273as com os mesmos iniciadores de 1; 3 - Digestão do plasmídeo pHANNIBAL contendo o fragmento de 273pb; 4 - Marcador de 100bp.

\section{IV.5 - Construção controle}

A esquematização do vetor controle foi realizada como mostra a figura 13, clonando-se o cassete do vetor pHANNIBAL no vetor pCAMBIA.

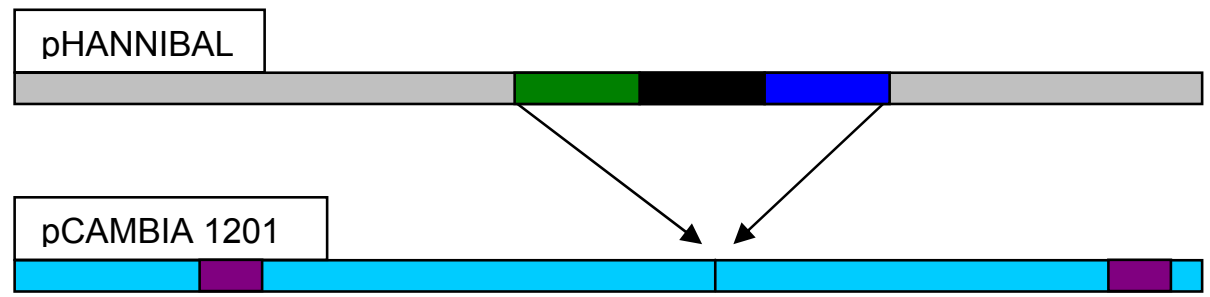

Promotor 35S

Íntron

Terminador OCS

Vetor CAMBIA

Bordas R e L

Figura 13: Representação da clonagem do plasmídeo pHANNIBAL no plasmídeo pCAMBIA 1201.

Para realização da construção do vetor controle esquematizado foi utilizado o mesmo protocolo de construção dos vetores pBKTnt1RT273ri e pBKTnt1RT470as. A parte que contém o promotor, o íntron e o terminador foi digerida por ação das enzimas de restrição Sac I e Pst I, assim como o vetor pCAMBIA 1201. Seguindo-se a relação inserto:vetor igual a 1:1, 3:1 e 5:1 para um total de $50 \mathrm{ng}$ de vetor, foi realizada a reação de ligação. Após transformação, 12 colônias brancas foram escolhidas para crescimento e extração de DNA em pequena escala. O DNA das colônias extraído foi digerido com as enzimas de restrição Sac I e Pst I sendo observado a presença de bandas em algumas colônias que correspondiam ao tamanho do inserto clonado (figura 14). 
A

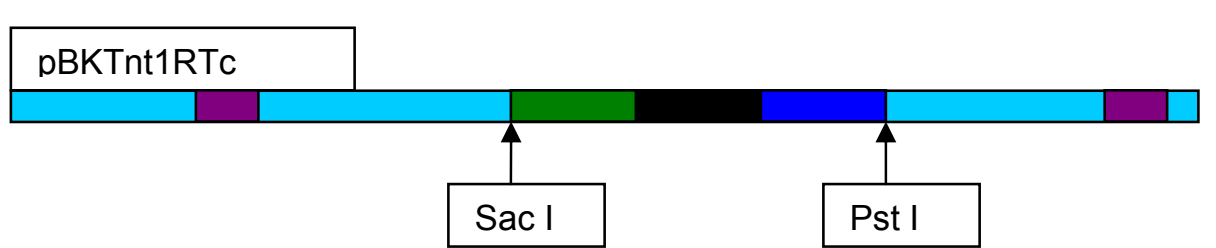

Promotor 355

Íntron

Terminador OCS

Vetor CAMBIA

Bordas R e L

B

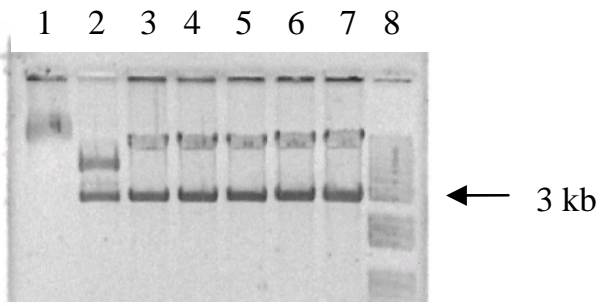

$9 \quad 10111213141516$

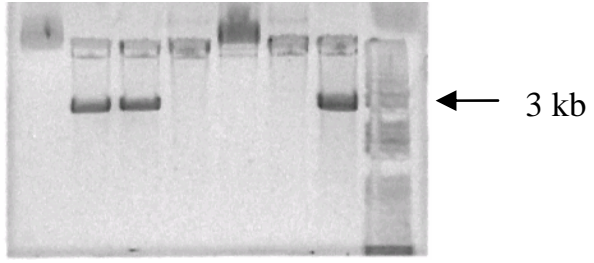

Figura 14: (A) Representação da digestão do vetor pBKTnt1RTc com as enzimas Sac I e Pst I. (B) Gel de eletroforese mostrando digestões com as enzimas Sac I e Pst I de diferentes colônias contendo o plasmídeo pBKTnt1RTc. 1 e 9 - pCAMBIA 1201 não digerido; 2 a 7 e 10 a 15 - diferentes colônias contendo o plasmídeo pBKTnt1RTc; 8 e 16 - Marcador 100pb

O tamanho esperado do fragmento é de 2960 pares de base que podem ser visualisados na maioria das colônias com excessão das colônias 12, 13 e 14 e da colônia 2 que possuium tamanho diferente do esperado.

Para continuação do trabalho, uma colônia contendo o inserto esperado foi escolhida. O vetor ficou sendo chamado de pBKTnt1RTc. 


\section{IV.6 - Construções desenvolvidas}

Resumo das construções desenvolvidas é mostrada na tabela a seguir:

\begin{tabular}{|l|l|}
\hline \multicolumn{1}{|c|}{ Construções } & \multicolumn{1}{c|}{ Características } \\
\hline pBKTnt1RT273ri & $\begin{array}{l}\text { Fragmento de 271pb amplificado do domínio de transcriptase } \\
\text { reversa do elemento Tnt1 clonado em sentido senso e anti-senso } \\
\text { no vetor pCAMBIA 1201. Esta construção desencadeará o } \\
\text { processo de inteferência de RNA em plantas de fumo. }\end{array}$ \\
\hline pBKTnt1RT470as & $\begin{array}{l}\text { Fragmento de 470pb amplificado do domínio da transcriptase } \\
\text { reversa do elemento Tnt1 clonado em sentido anti-senso no vetor } \\
\text { pCAMBIA 1201. Esta construção desencadeará o processo de } \\
\text { inibição anti-senso. }\end{array}$ \\
\hline pBKTnt1RT273asm & $\begin{array}{l}\text { Fragmento de 271pb amplificado do domínio de transcriptase } \\
\text { reversa do elemento Tnt1 clonado em sentido Anti-senso no vetor } \\
\text { pCAMBIA 1201. Esta construção desencadeará o processo de } \\
\text { inibição anti-senso e têm como objetivo servir de comparação para } \\
\text { os resultados obtidos com a construção pBKTnt1RT470as. }\end{array}$ \\
\hline pBKTnt1RTc & $\begin{array}{l}\text { Íntron do vetor pHANNIBAL clonado no vetor pCAMBIA 1201. Esta } \\
\text { construção foi desenvolvida para servir de controle para as outras } \\
\text { duas construçães. }\end{array}$ \\
\hline
\end{tabular}

Tabela 1:Construções realizadas com suas respectivas funções

Para confirmar todas as construções realizadas mostradas na tabela 1, foram realizadas reações de polimerização em cadeia utilizando-se os iniciadores com os quais foram feitas as amplificações do retroelemento Tnt1 contido no plasmídeo pBSX1. Foram utilizados apenas um par dos iniciadores, que é o par que amplifica o fragmento menor em sentido antisenso (figura 15). 
A

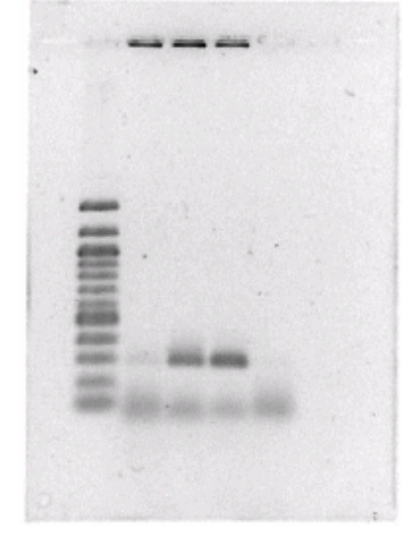

B

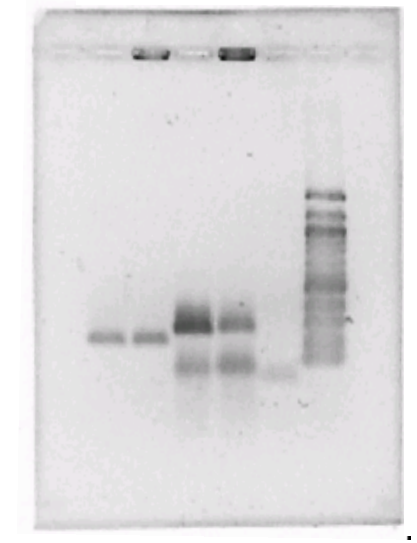

Figura 15: Verificação de transformação de colônias de Agrobacterium tumefasciens. (A) Gel de agarose com reação de amplificação em cadeia do plasmídeo pBKTnt1RT273ri. 1 - Ladder 100pb; 2 ,3 e 4 - amplificações de colônias contendo o plasmídeo pBKTnt1RT 273ri; 5 - controle negativo. (B) Gel de agarose com reação de amplificação em cadeia dos plasmídeos pBKTnt1RT470as e pBKTnt1RTc. 1 controle positivo de amplificação do gene GUS; 2 - amplificação de colônia contendo o plasmídeo pBKTnt1RTc; 3 - controle positivo de amplificação do plasmídeo pBKTnt1RT470as; 4 - Amplificação de colônia contendo o plasmídeo pBKTnt1RT470as; 5 - controle negativo de amplificação; 6 - Ladder 100pb.

A figura 15 ilustra que todas as contruções foram clonadas com sucesso em Agrobacterium tumefasciens. As amplificações comprovam a presença dos vetores e o próximo passo foi a transformação de folhas de fumo.

\section{IV.7 - Transformação de tecidos foliares de plantas de fumo}

A transformação de folhas de fumo foi realizada de acordo com a figura 16. 


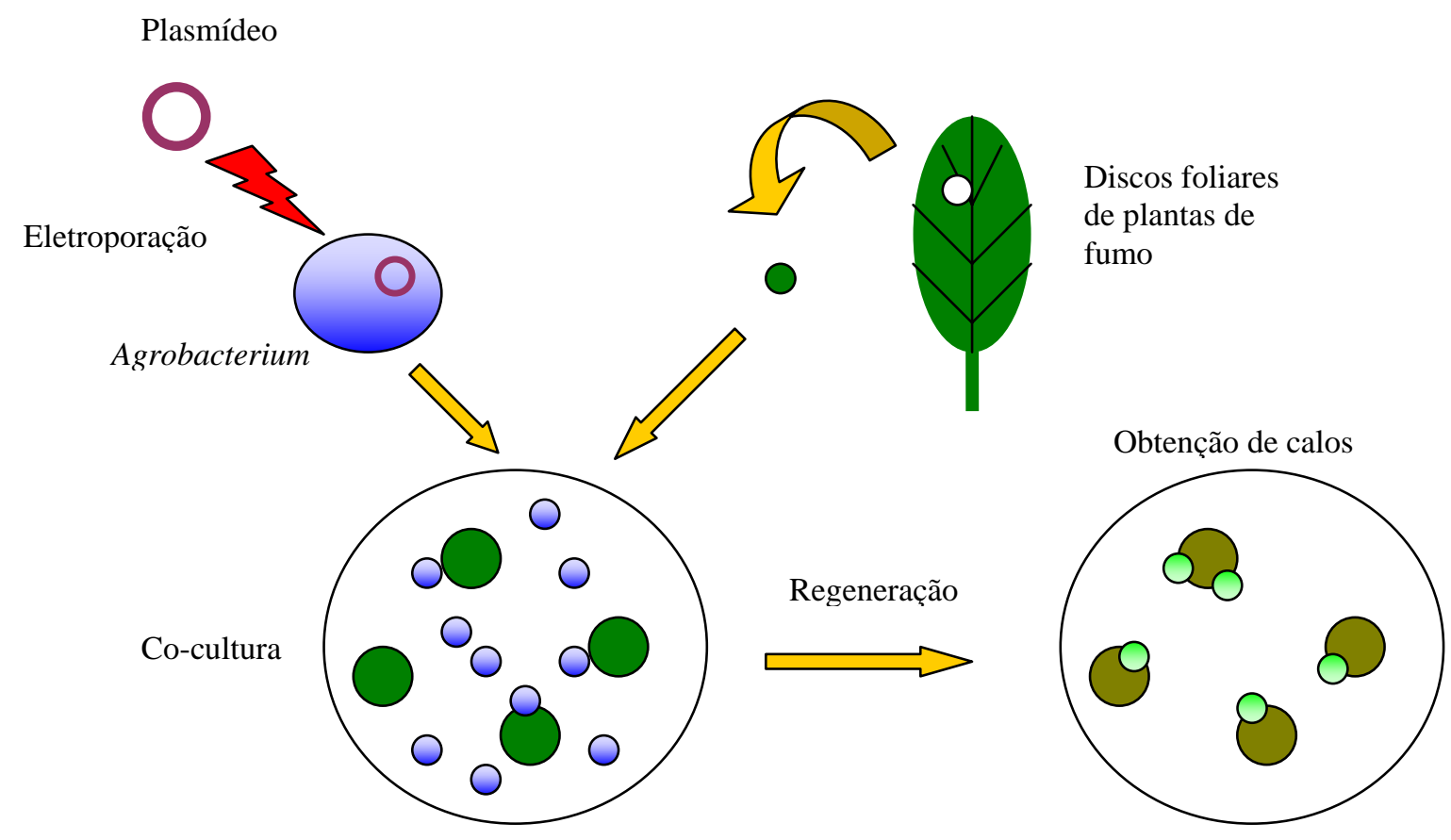

Figura 16: Esauema de transformacão de folhas de fumo

Com os discos separados em placas de petri, as bactérias eram preparadas após crescimento como descrito no ítem III.10. Os discos após co-cultura, foram colocados em meio MS-30 acrescido de 6BA (1 mg/ml), higromicina $(30 \mu \mathrm{g} / \mathrm{ml})$ e cefotaxime $(200 \mu \mathrm{g} / \mathrm{ml})$, ficando em sala de vegetação.

Os discos foliares foram fotografados logo após a co-cultura e o desenvolvimento foi acompanhado ao longo do tempo por no máximo 45 dias. A figura 17 A, B e C mostra o primeiro experimento de transformação de discos com o aparecimento dos primeiros calos.

\section{IV.8 - Experimentos de transformação}


De um total de 10 experimentos independentes e espaçados a 15 dias de intervalo, 3 produziram resultados que foram contabilizados quanto ao tempo em dias para aparecimento de calos, número de calos total e número de regenerantes. As tabelas 2, 3 e 4 apresentam os resultados obtidos. As figuras 17A, 17D, 17E e 17F exemplificam as tabelas abaixo.

\begin{tabular}{|c|c|c|c|c||}
\hline Experimento & $\begin{array}{c}\text { Número de } \\
\text { discos }\end{array}$ & $\begin{array}{c}\text { Aparecimento } \\
\text { do primeiro } \\
\text { calo (dias) }\end{array}$ & $\begin{array}{c}\text { Número de } \\
\text { calos }\end{array}$ & $\begin{array}{c}\text { Números de } \\
\text { regenerantes }\end{array}$ \\
\hline pBKTnt1RT271ri & 30 & 20 & 2 & 3 \\
\hline pBKTnt1RT470as & 30 & 15 & 10 & 5 \\
\hline pBKTnt1RTasm & 30 & 15 & 11 & 11 \\
\hline pBKTnt1RTc & 28 & 15 & 2 & 2 \\
\hline LBA 4404 & 28 & 15 & 9 & 4 \\
\hline
\end{tabular}

Tabela 2

\begin{tabular}{|c|c|c|c|c|}
\hline Experimento & $\begin{array}{c}\text { Número de } \\
\text { discos }\end{array}$ & $\begin{array}{c}\text { Aparecimento } \\
\text { do primeiro } \\
\text { calo (dias) }\end{array}$ & $\begin{array}{c}\text { Número de } \\
\text { calos }\end{array}$ & $\begin{array}{c}\text { Números de } \\
\text { regenerantes }\end{array}$ \\
\hline pBKTnt1RT271ri & 30 & 20 & 3 & 3 \\
\hline pBKTnt1RT470as & 29 & 20 & 1 & 1 \\
\hline pBKTnt1RTasm & 28 & 15 & 3 & 3 \\
\hline pBKTnt1RTc & 29 & 15 & 2 & 2 \\
\hline LBA 4404 & 29 & 15 & 27 & 8 \\
\hline
\end{tabular}

Tabela 3

Experimento
Número de discos
Aparecimento do primeiro

\section{Número de} calos 


\begin{tabular}{||c|c|c|c|c||}
\hline 9 & & calo (dias) & & \\
\hline pBKTnt1RT271ri & 30 & 0 & 0 & 0 \\
\hline pBKTnt1RT470as & 30 & 0 & 0 & 0 \\
\hline pBKTnt1RTasm & 30 & 20 & 3 & 3 \\
\hline pBKTnt1RTc & 30 & 20 & 2 & 1 \\
\hline LBA 4404 & 30 & 10 & 27 & 2 \\
\hline
\end{tabular}

Tabela 4

Deste material foram regeneradas um total de 61 plantas das quais 14 controle sem T-DNA, 6 controle com T-DNA, dezessete I, sete AS, dezessete ASm. Destas conseguimos enraizar nove em vaso para coleta de sementes (um controle sem T-DNA, um controle com T-DNA, seis I, um ASm). Doze linhagens ainda são mantidas in vitro das quais uma é controle com T-DNA, cinco são linhagens I, duas são linhagens AS e quatro são ASm. 


$\begin{array}{cccccc}\text { T1 } & \text { sem inserto } & & & & \\ \text { T2 } & & 1 & 3 & 1 & \\ \text { T3 } & 2 & 1 & 3 & 5 & 11 \\ \text { T7 } & 4 & 2 & 3 & 1 & 3 \\ \text { T8 } & 8 & 2 & & & 3 \\ \text { T9 } & & & 17 & 7 & 17 \\ \text { Total } & 14 & 6 & 5 & 2 & 4 \\ \text { regenerantes } & 0 & 1 & 6 & \text { n.d. } & 1 \\ \text { in vitro } & 1 & 1 & 2 & 3 & 0\end{array}$

Tabela 5: Coleção de regenerantes de diversas transformações que estão estabelecidos no laboratório.

\section{IV.9 - Fenótipo de plantas regeneradas}

Plantas regeneradas de experimentos de transformação primeiramente foram testadas para confirmação de inserção as construções no genoma através de ensaio histoquímico. A visualização da tonalidade azul devido a presença do gene GUS dá certeza do evento de transformação do indivíduo, e que poderia ser preservado para continuidade das análises fenotípicas dos regenerantes. Todas as 47 linhagens de regenererantes que carregavam alguma das versões com inserto T-DNA (C, I, AS e ASm) passaram por teste histoquímico para confirmação de transformação e a figura $17 \mathrm{G}$ ilustra o resultado obtido para três regenerantes.

A coloração azul nas folhas que passaram pelo teste histoquímico comprova que as plantas estão com as construções inseridas no genoma e 
estas sendo transcritas. As plantas separadas dos calos provindos dos experimentos de transformação foram mantidas em frascos individuais em meio MS-30. Quando as plantas são retiradas de seus calos, o desenvolvimento ocorre normalmente até aproximadamente sete dias da separação (figura 17J; 17K; 17L) quando a partir daí começam a aparecer mudanças.

Pelas figuras podemos ver que tanto as plantas que possuem as construções quanto as selvagens, neste estágio de desenvolvimento apresentam fenótipos idênticos, e não percebemos nehum tipo de mudança visível a não ser a já citada defasagem de crescimento. O desenvolvimento dos regenerantes seguem idênticos até aproximadamente sete dias após a separação dos calos quando mudanças significativas começam a aparecer mostrados pelas figuras $17 \mathrm{M} ; 17 \mathrm{~N} ; 17 \mathrm{O}$.

As figuras nos mostram folhas com vários pontos de necrose em sua parte adaxial. Estes pontos não estão presentes nos indivíduos selvagens ou em outros indivíduos transformados e não se limitam apenas a folhas mais antigas, estão também presentes em folhas novas descartando a possibilidade de que seja um envelhecimento natural da folha. As folhas recém formadas não apresentam sinais de necrose, só aparecendo o sintoma após aproximadamente dez dias de separação do calo.

Após aproximadamente 30 dias de desenvolvimento tendo como início o isolamento da planta do calo, as plantas foram repicadas para recipientes 
novos de modo a renovar o meio e seguir acompanhando o desenvolvimento. Algumas plantas repicadas que continham as necroses, apresentaram uma acentuada queda no desenvolvimento. Estas plantas praticamente não desenvolveram folhas, não apresentaram raízes e seu tamanho continuou por um período de aproximadamente 60 dias sem alteração. Após 30 dias do segundo repique, as plantas, mesmo sem apresentar desenvolvimento, foram transferidas para meio de cultura novo. Mesmo trocando-se o meio de cultura, não observamos crescimento expressivo, como mostrado nas figuras $17 \mathrm{P}$ e $17 \mathrm{Q}$.

Estas plantas se encontraram com esta aparência por aproximadamente 120 dias após a separação do calo, onde não houve um desenvolvimento expressivo na parte aérea e tão pouco o aparecimento de raízes. No conjunto das plantas que contém a construção pBKTnt1RT273ri obtidas, há uma fração que apresenta raízes e estas serão transferidas para terra de modo a obtermos sementes. 

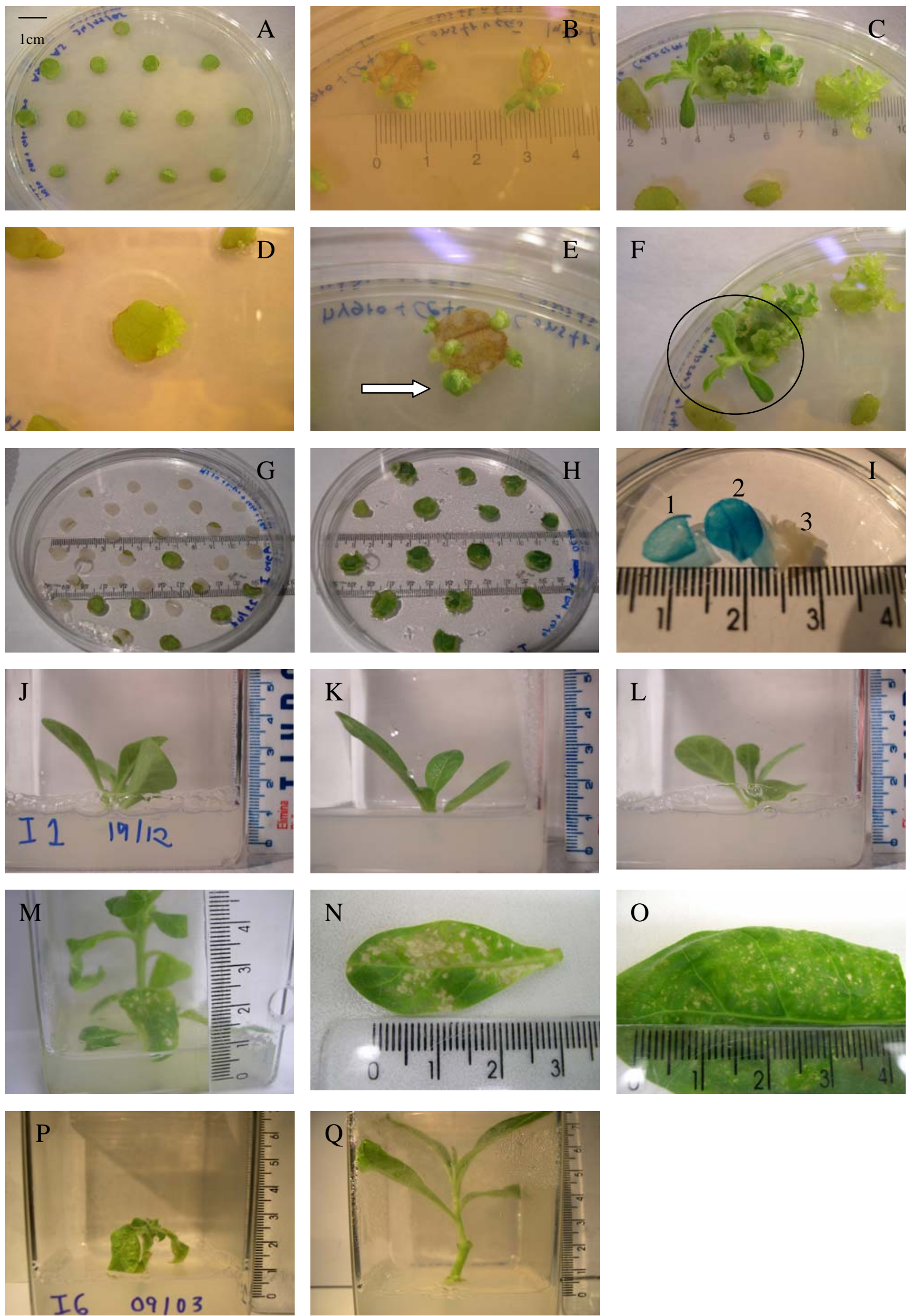
Figura 17: Prancha com resultados de transformação:

(A) Discos foliares dispostos em placa de petri após co-cultura com Agrobacterium para transformação. Esta foi a disponibilização dos discos nas placas podendo assim serem contabilizados. (B) Calos presentes em discos foliares transformados com o plasmídeo pBKTnt1Rtri (20 dias após co-cultura). (C) Calos do controle de regeneração com 20 dias após co-cultura. (D) Aparecimento dos primeiros calos nos discos foliares. (E) Contabilização dos calos nos discos foliares. (F) Regenerantes que foram separados dos seus calos. (G) Foto ilustrativa do ensaio histoquímico realizado com folhas de plantas regeneradas de calos formados dos experimentos com discos foliares. 1- T1I1; 2- T2AS2; 3- T2C1. (J) T1I1 após 5 dias de separação do calo. (K) T7AS10 após 5 dias de separação do calo. (L) T1C2 após 5 dias de separação do calo. (M) Visão geral do indivíduo T1I1 após 20 dias da separação do calo. (N) Folha basal do indivíduo T1I1. (O) Folha apical do indivíduo T1I1. (P) Indivíduo T1I6 15 dias após segundo repique. (Q) Indivíduo T1C2 com 15 dias após segundo repique.

Em nossos últimos experimentos, obtivemos um conjunto de plantas que exemplificam muito bem o fenótipo das plantas transformadas com a construção pBKTnt1RT273ri (figura 18 e 19).

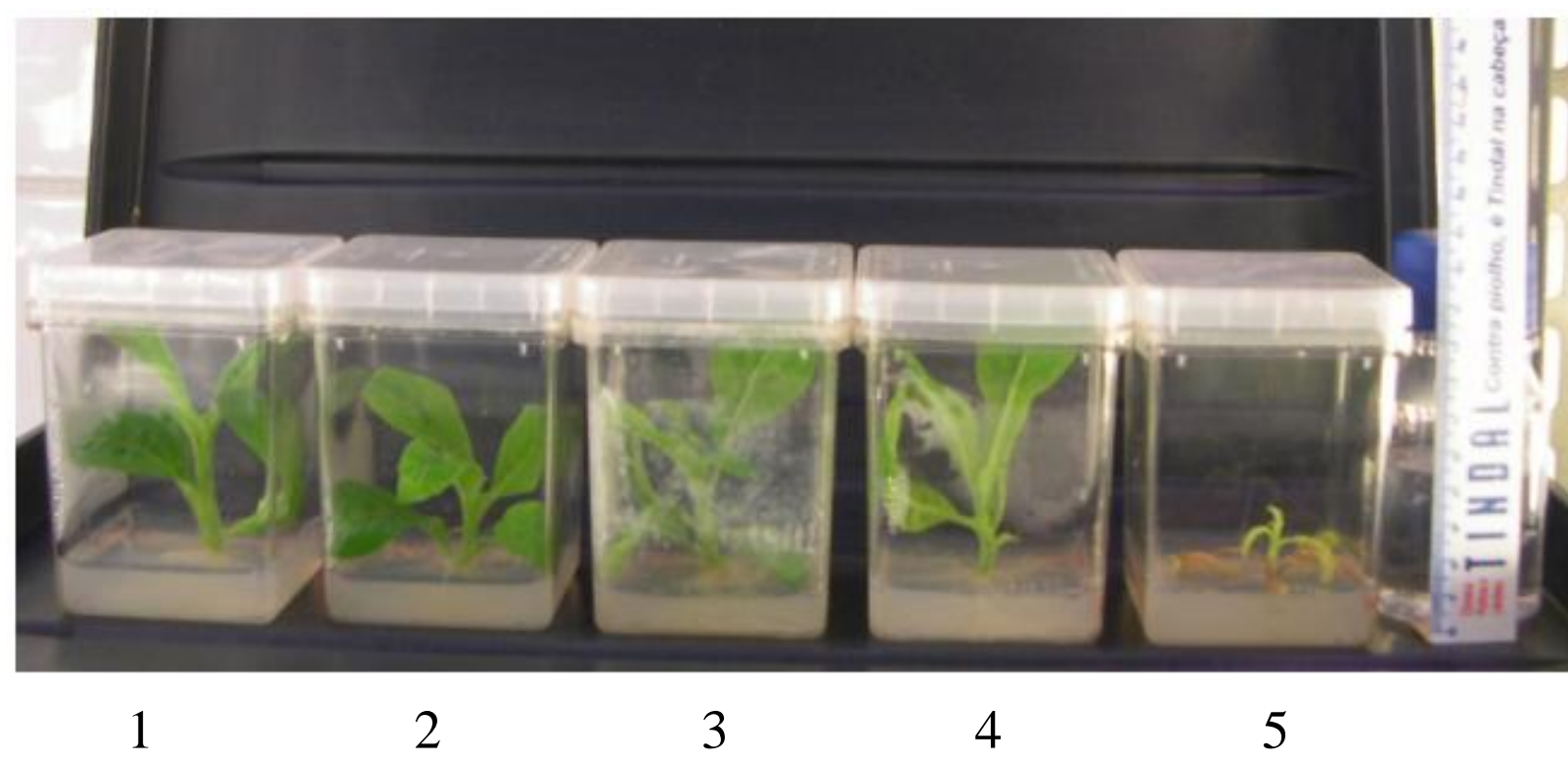

Figura 18: Comparação de plantas regeneradas a partir de calos oriundos de cocultura. As plantas se apresentam com 20 dias após separação do calo, exceto a planta 5 que possui 30 dias. 1 - indivíduo C; 2 - indivíduo ASm; 3 - indivíduo ASm; 4 indivíduo AS; 5 - indivíduo I. 
Na figura 18 podemos visualizar que a planta que contém a construção que gera interferência não apresenta desenvolvimento como observado nas demais plantas, corroborando os resultados anteriormente obtidos (figura 17P e 17Q). A ausência de raízes apresentada pelas plantas que contém a construção pBKTnt1RT271ri é observada na figura 19.

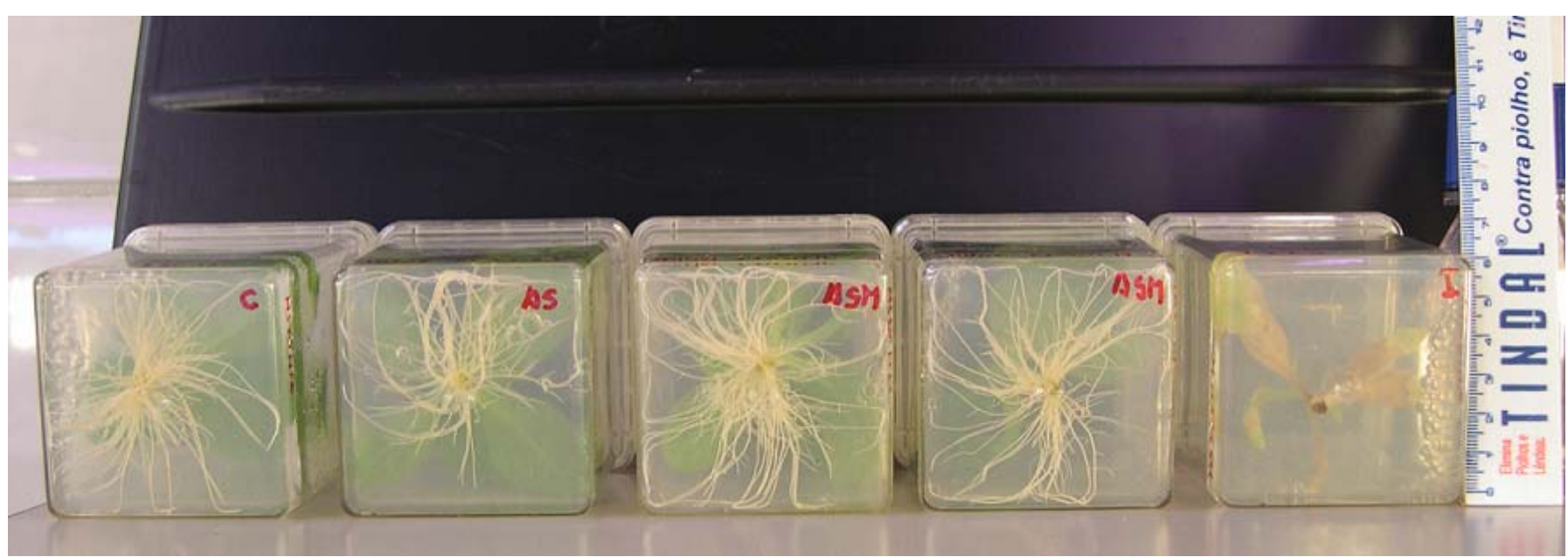

Figura 19 - Comparação de plantas regeneradas provindas de co-cultura. As plantas se apresentam com 20 dias após separação do calo, exceto a planta I que possui 30 dias. C - Indivíduo C; AS - indivíduo AS; ASM - indivíduo ASm; I - indivíduo interferência.

A figura 20 nos mostra calos em regeneração. Podemos notar pela figura o atraso na regeneração de discos transformados com as construções pBKTnt1RT273asm; pBKTnt1RT470as e pBKTnt1RT273ri em comparação com regeneração de discos selvagens e transformados com a construção controle. 


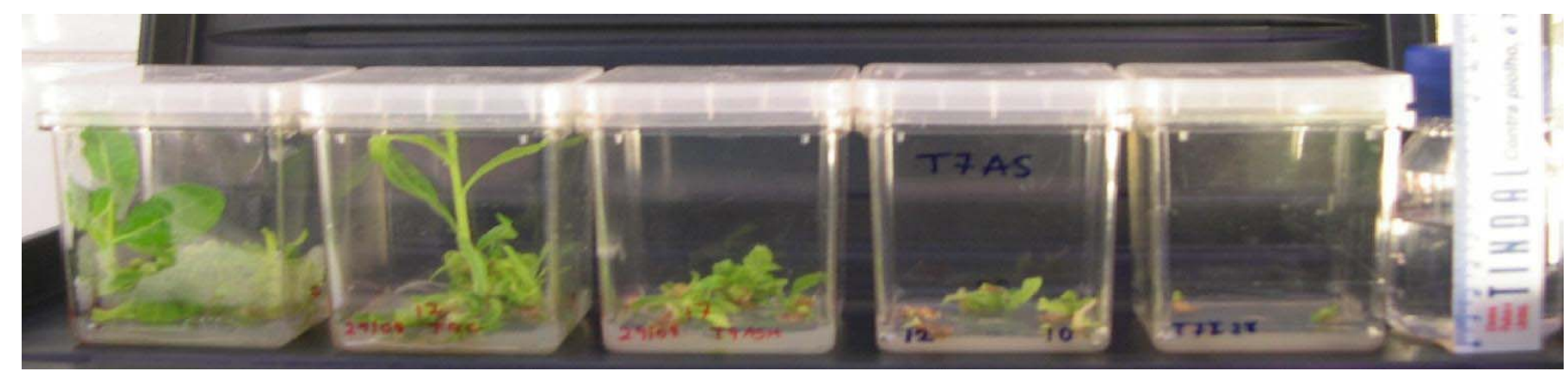

Figura 20: Regeneração de discos foliares. 1 - Selvagem; 2 - discos transformados com a construção controle; 3 - discos transformados com a construção pBKTnt1RT273asm; 4 - discos transformados com a construção pBKTnt1RT470as; 5 - discos transformados com a construção pBKTnt1RT273ri.

\section{IV.10 - Análise de RNA das plantas transformadas}

A análise de RNA foi realizada através de experimentos de northern blot. Os experimentos foram feitos apartir de folhas de todas as linhagens de plantas transgênicas obtidas assim como de planta selvagem. A figura 20 apresenta os resultados obtidos da análise de RNA.

$\begin{array}{lllll}1 & 2 & 3 & 4 & 5\end{array}$

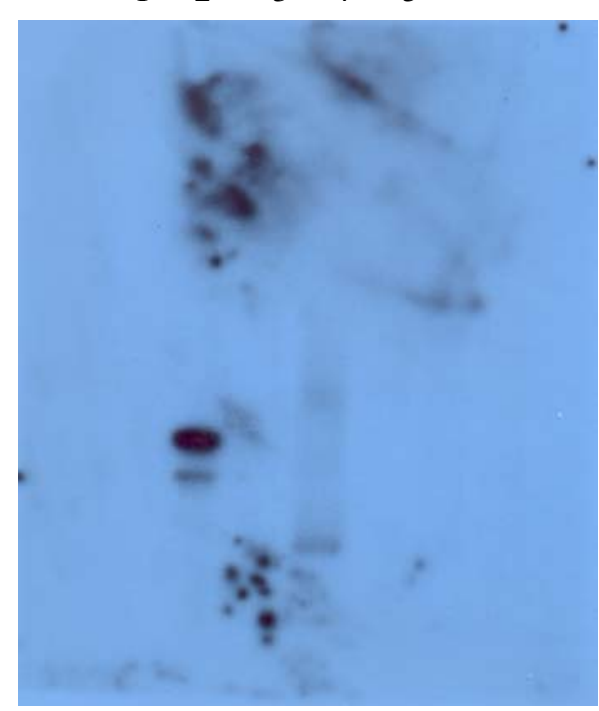

A

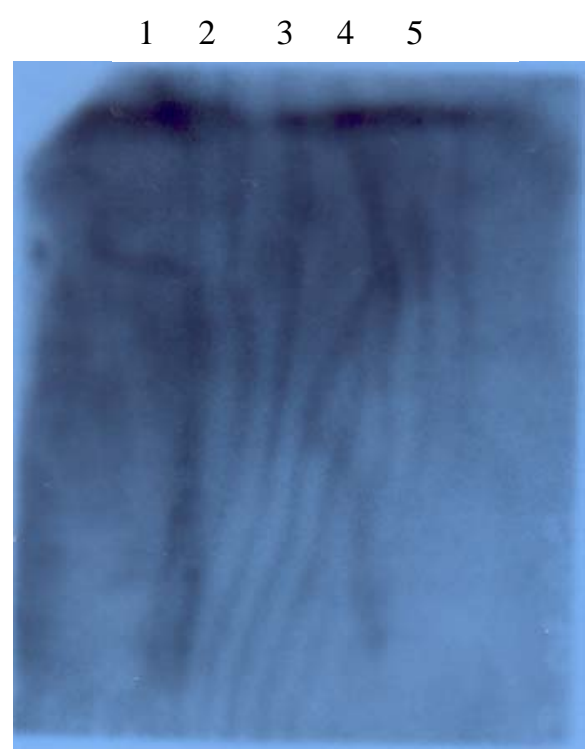

B

Figura 21: (A) Northern blot das plantas trangênicas obtidas utilizando a sonda para o elemento Tnt1 (A) e Tto1(B). As membranas são duplicatas e possuem RNA dos mesmos indivíduos. 1 - idivíduo I; 2 - idivíduo AS; 3 -indivíduo ASm; 4 - indivíduo C; 5 - indivíduo selvagem. 


\section{V - DISCUSSÃO}

No contexto geral de investigar se os elementos de transposição têm uma função potencial no sistema vegetal, o objetivo específico deste trabalho foi o de averiguar o envolvimento do retrotransposon Tnt1 na resposta de regeneração e desenvolvimento de plantas in vitro. Sabe-se a partir de resultados publicados na literatura que Tnt1 expressa-se de modo constitutivo em raízes de plantas de fumo e que sua expressão, e eventual transposição, é induzida em condições de estresse biótico e abiótico (Grandbastien et al, 1997; Grandbastien et al, 2005; Melayah et al, 2001). Existem hoje duas hipóteses formadas, baseadas em estudos realizados com o intuito de entender a função dos elementos de transposição. A primeira defende o ponto de vista de que os elementos de transposição são parasitas; e a segunda, defende que os elementos de transposição são essenciais e desempenham função no organismo que os contém. A figura 22 ilustra as diferentes hipóteses para o lemento Tnt1, alvo de estudos do presente trabalho. 


\section{Função dos elementos de transposição: Parasitas ou essenciais?}

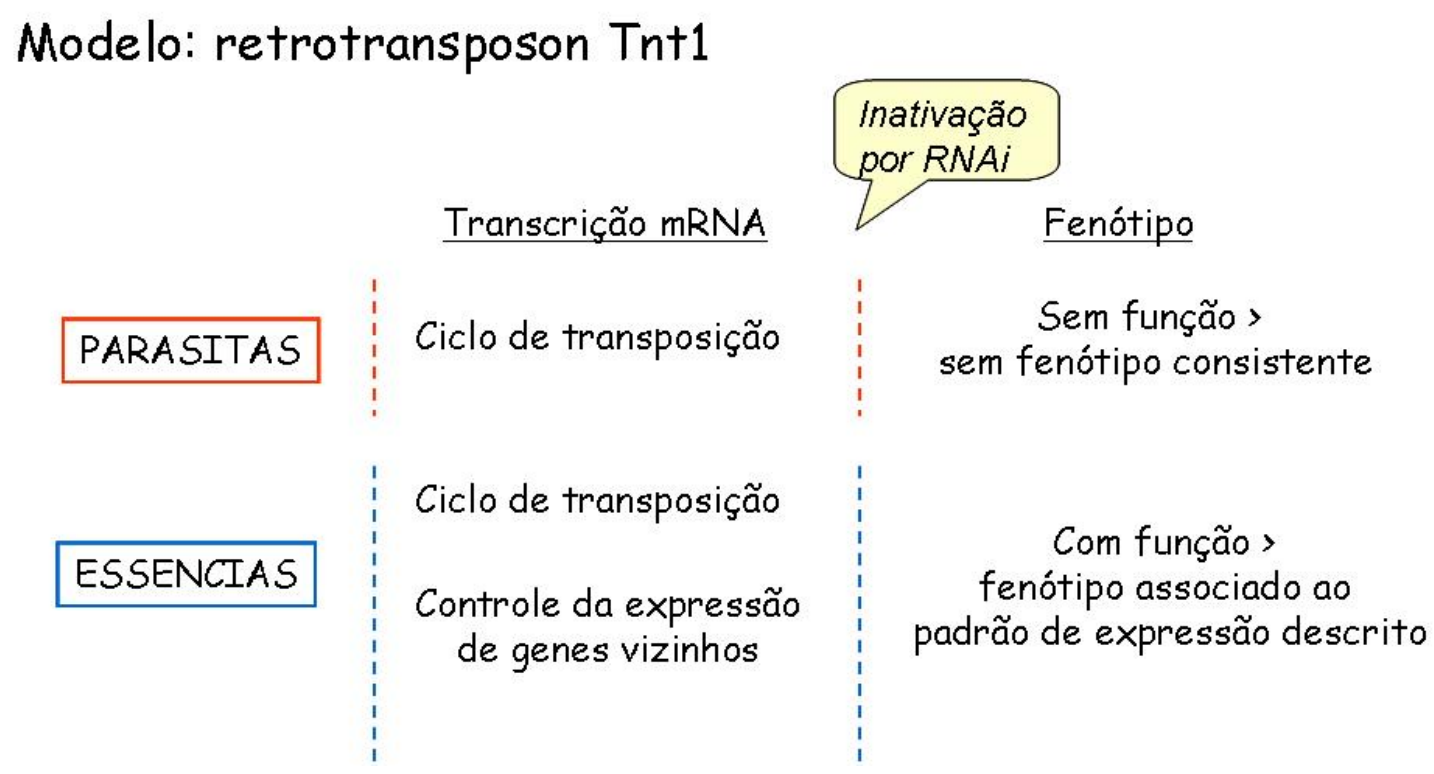

Figura 22: hipótese da função do retroelemento Tnt1 em plantas de fumo.

Para se estudar a função de um gene pode-se fazê-lo pela obtenção de um mutante natural ou através do uso da genética reversa, a estratégia pela qual interfere-se na expressão do gene e analisa-se o fenótipo de plantas regenerantes e de sua descendência. Estudar a função do conjunto de uma família multigênica é complicado, entretanto esta dificuldade foi contornada com a descoberta recente do mecanismo de intereferência de RNA descrito em diversos organismos (Fritz et al, 2006; Grishok A, 2005). Este mecanismo produz moléculas de RNA de pequeno tamanho (21-25 nucleotídeos) em orientação anti-senso que ao se parearem com as moléculas de mRNA nativas acionam a clivagem específica deste pela enzima DICER. Este mecanismo torna, portanto, possível a inativação de um membro da família ou do conjunto dos membros se a região alvo de inativação por RNAi selecionada for específica de um membro ou comum a 
todos.

Neste trabalho a fim de estudar a função do retrotransposon Tnt1 selecionou-se a estratégia de inativação por RNAi de modo a abolir a expressão do elemento e averiguar se há o aparecimento de um fenótipo associado como esquematizado na figura 16. Como controles experimentais do evento de inativação por construções que geram grampo que induzem a interferência de RNA, foram utilizadas construções sem inserto e construções nas quais apenas o fragmento em anti-senso está presente sendo todos comparados a plantas inoculadas e regeneradas com bactérias desarmadas sem fragmento T passível de transferência.

A região mais conservada entre os retrotransposons de uma mesma família é o domínio da transcriptase reversa (Grandbastien et al, 1989; Boeke, 2003). A superfamília Tnt1 de elementos encontrada bem caracterizada em Solanaceae diversifica-se pela variação da região U3 da LTR, a região codificante é conservada (Costa et al, 1999, Manetti et al, 2007). Por este motivo, a região mais conservada entre dois retrotransposons de famílias distintas foi selecionada como região alvo para o desenho dos iniciadores que amplificariam a região a ser inativada. Uma região conservada entre os dois elementos seria bastante interessante para 0 desenvolvimento de construções gênicas para o desencadeamento da interferência de RNA, pois com apenas uma construção poderíamos inibir os RNAs mensageiros dos elementos da família Tnt1 nas diferentes espécies de Solanaceae. A construção teria como alvo o domínio da transcriptase reversa no mRNA dos retroelementos.

Segundo a literatura, a inativação cruzada só poderia ocorrer se entre os elementos houvesse $100 \%$ de similaridade de nucleotídeos (Waterhouse 
et al, 2001; Voinnet, 2001; Hannon, 2002), ainda que exceções existam (Brodersen e Voinnet, 2006). Quanto ao tamanho das construções, não existe um consenso na literatura. Foram realizados trabalhos de inibição com construções que variam de 100 pares de base até 800 pares de base, além de existir especulações de que com apenas 21 nucleotídeos poderíamos desencadear interferência em plantas (Wesley et al, 2001).

Levando em conta todas as considerações feitas, a estratégia utilizada foi de desenhar iniciadores nas regiões de maior identidade, como mostrado na figura 5. Como estas regiões são muito pequenas para servirem como alvo para a inibição pós transcricional, elas foram utilizadas para desenho de iniciadores que serviriam para amplificação da região correspondente em vetor contendo Tnt1.

Devido à falta de consenso na literatura quanto ao tamanho ideal da construção que gera o dsRNA (figura 5), dois fragmentos de tamanho distintos foram amplificados da mesma região da RT. Para tal, três inicadores foram elaborados, um no sentido direto (caixa em azul) e os demais no sentido reverso (caixas em vermelho e verde). A partir dos fragmentos amplificados foi obtida uma construção interferência Rl; (273sas) e duas antisenso (AS; 470as e ASM; 273as).

No primeiro experimento, notou-se claramente um atraso em comparação com o controle de crescimento. Os primeiros calos no controle de regeneração apareceram com 13 dias após co-cultura enquanto na transformação com o vetor pBKTnt1RT273ri apareceram com 18 dias após co-cultura. Fato bastante curioso foi o que aconteceu com relação à construção pBKTnt1RT470as. Os discos foliares inoculados com esta construção não geraram calos nem regenerantes. Nas transformações 
subsequentes, novamente os discos foliares inoculados com a construção pBKTnt1RT470as não apresentaram a formação de calos sendo que as demais apresentaram. Os discos foliares inoculados com a construção pBKTnt1RT273ri continuaram apresentando atraso no aparecimento de calos. Em função deste atraso a construção pBKTnt1RT273asm serviu de base para comparação com os resultados obtidos com a construção pBKTnt1RT470as.

O fato do não aparecimento de regenerantes com a transformação pBKTnt1RT470as foi relacionado ao próprio experimento de transformação. A retirada de discos foliares e a co-cultura com Agrobacterium tumefaciens é um processo muito estressante ao tecido vegetal. Como os discos foram retirados de uma mesma folha de fumo, e não aleatoriamente de outras folhas e outras plantas, a folha utilizada poderia já estar senescente ou ser muito jovem, o que pode ter influenciado na regeneração e na própria resistência ao processo de transformação.

Foi notado um atraso de 5 dias no aparecimento de calos nos discos contendo o vetor pBKTnt1RT273ri sendo que as construções pBKTnt1RT470as e pBKTnt1RT273asm apresentam um comportamento variável entre o controle e a construção de interferência. Os resultados obtidos ainda não tem um valor estatístico porém, nota-se que o vetor pBKTnt1273ri apresenta um atraso associado a um menor número de calos formados.

A co-cultura dos discos foliares apresentou grande número de mortes de discos. Houve mortes em todas as transformações, mas o que chamou nossa atenção foi o grande número de discos mortos nas transformações com as construções pBKTnt1RT273ri e pBKTnt1RT470as. Nestas duas 
transformações, mais de $50 \%$ dos discos morreram entre 3 e 5 dias após a co-cultura em todos os experimentos de transformação. Em função destes resultados estabeleceu-se que para os novos experimentos a serem realizados serão utilizados fragmentos de discos foliares de maior diâmetro.

Independente destes resultados verificou-se em experimentos realizados pelo Dr. J. Casacuberta em nosso laboratório que a agroinfiltração destas construções em folhas de fumo resultava em entrada antecipada de senescência foliar justamente com as construções ASM e RI e as folhas controle e não agroinfiltradas não apresentavam fenótipo (resultados não publicados).

Em função destes resultados é possível que a mortalidade dos discos observada nos experimentos de co-cultura fossem causadas pelas construções já que estes ficaram idênticos às áreas necrosadas no experimento de infiltração. Outro fator que corrobora que as mortes foram ocasionadas pelas construções é o fato de que esta mortalidade de mais de $50 \%$ dos discos só aconteceram nas construções pBKTnt1RT273ri (figura 17G) e pBKTnt1RT470as seguidas em número de mortes pela construção pBKTnt1RT273asm. A construção controle e selvagem, apresentaram mortalidade bastante reduzida (figura $17 \mathrm{H}$ ).

Os calos formados a partir de discos foliares foram separados para que diferentes eventos de transformação fossem preservados. Esses calos foram estimulados à regeneração e o fenótipo dos indivíduos regenerantes foi analisado. Todas as plantas regeneradas foram testadas quanto ao evento de transformação através do ensaio histoquímico (figura 17I) o que permitiu que apenas as plantas que apresentaram resultado positivo para o teste histoquímico fossem propagadas. 
No início, os indivíduos regenerados não apresentaram diferenças fenotípicas além do atraso visto no aparecimento de calos (figura 17J; $17 \mathrm{~K} \mathrm{e}$ 17L)). A partir de sete dias de separação do calo, as plantas que expressavam as construções pBKTnt1RT273ri, pBKTnt1RT470as e pBKTnt1RT273asm, apresentaram sinais de necrose nas folhas (figura $17 \mathrm{~N}$ e 170). A construção controle e os indívíduos selvagens mantidos sob mesmas condições das plantas transformadas não apresentaram esses sinais.

Os pontos de necrose se distribuem por toda a folha e não se manifestam apenas em folhas mais velhas, estes pontos também são observados nas folhas mais jovens. Isso permitiu descartar a hipótese de que se tratava de senescência da folha. Esses sinais se apresentam como pontos muito pequenos de menos de $1 \mathrm{~mm}$ de diâmetro. Em algumas folhas, estes pontos são tão numerosos que uma observação menos cuidadosa levaria à conclusão de que se tratavam de áreas de necrose (figura 17N).

O fenótipo observado sugere que se trate de uma resposta de hipersensibilidade. A resposta de hipersensibilidade é um tipo de morte programada celular (Lam, 2004). Geralmente, esta resposta acontece como defesa das plantas contra patógenos. A planta programa a morte celular ao redor da célula infectada evitando que o patógeno se espalhe por áreas maiores (Mittler \& Rizhsky, 2000; Liu et al, 2005; Kachroo et al, 2006). A morte celular programada como defesa é ativada quando um gene de resistência da planta reconhece direta ou indiretamente (por meio de eliciadores produzidos por genes de avirulência) um patógeno (Ehrenfeld et al, 2005). Para resposta de hipersensibilidade, é preciso haver no organismo atacado um gene de resistência $(R)$ que reconheça o gene da avirulência do patógeno (Avr) (Hammond-Kosack \& Parker, 1996). É possível postular que a 
inibição do retroelemento Tnt1 de algum modo esteja desencadeando uma resposta de defesa nas plantas. Diante deste fato, duas hipóteses foram formuladas:

(i) O retrotransposon Tnt1 participa de uma resposta de defesa nas plantas.

(ii) O sistema de defesa viral entre o gene de avirulência (Avr) e o gene de resistência na planta $(R)$ é induzido pelo evento de transformação com as construções.

No caso (i) os resultados corroboram os estudos de Mhiri et al, 1996 e 1997, e os estudos realizados por Grandbastien et al, 2005. Nesses trabalhos, ficam claras as evidências de que o elemento Tnt1 possui estreita relação ao desencadeamento da resposta de estresse na planta. Pelo fenótipo apresentado pelas plantas transgênicas adquiridas neste trabalho, obtivemos indícios que o retroelemento está vinculado à resposta primária de defesa em tabaco. Esta afirmação está embasada na resposta de hipersensibilidade causada nas plantas regenerantes pelas construções tanto de interferência quanto anti-senso. As construções visam a degradação do mRNA dos elemento para que ele não seja traduzido e não desempenhe sua possível função. Levando-se em conta que o retroelemento Tnt1 possui uma expressão basal no organismo (Grandbastien et al, 2005), a falta dessa expressão basal, ocasionada pelas construções desenvolvidas, pode ser um sinal para o desencadeamento de resposta de defesa da planta, comprovando a relação do retroelemento Tnt1 ao desencadeamento de resposta de defesa no organsimo.

O tipo de resposta de defesa obtida é um outro indício do sistema de defesa em que o elemento está relacionado. A resposta de hipersensibilidade 
é um tipo de resposta de defesa primária nas plantas, uma resposta inata do sistema imune (Liu et al, 2005). Como a inibição do elemento Tnt1 gerou uma resposta de hipersensibilidade nas plantas transformantes, relacionamos o elemento com a resposta inata de defesa.

Os outros estudos realizados com o elemento Tnt1 (citados acima), observaram que o promotor do elemento era ativado em diferentes situações de estresse causados. Se esses elementos estiverem realmente relacionados com a resposta primária de defesa, eles seriam ativados em qualquer situação de estresse sofrida pelo organismo, explicando os resultados observados nos trabalhos.

A segunda hipótese formulada está relacionada com o sistema de defesa em que o organismo atacado reconhece o produto de um gene de avirulência de um patógeno por um gene de resitência e este reconhecimento gera uma resposta de hipersensibilidade (Hammond-Kosack e Parker, 1996; Greenberg e Yao; 2004).

A análise de expressão por hibridação de membrana contendo RNA total de cinco plantas permitiu verificar que o elemento Tto1 não é induzido nas condições de nossos experimentos e que portanto o fenótipo observado trata-se da interferência na expressão do retroelemento Tnt1. No entanto, cabe ressaltar que os resultados não devem ser considerados representativos, pois apenas uma linhagem de cada construção foi analisada. É necessário ampliar a análise de expressão com outras linhagens independentes com e sem fenótipo de modo a dar consistência e robustez às observações feitas.

Os resultados apresentados neste trabalho são inéditos e caracterizam pela primeira vez que a inativação potencial de elementos de transposição da 
família do retrotransposon Tnt1 tem um papel potencial no ciclo biológico de um organismo. 


\section{VI - RESUMO}

Elementos de transposição são sequências de DNA que possuem a habilidade de se transpor. Estes elementos são divididos em dois grupos de acordo com seu mecanismo de transposição. Aqueles que se transpõem diretamente a partir de moléculas de DNA são chamados de transposons e os que se transpõem através de um intermediário de RNA são chamados de retrotransposons.

Os retrotransposons são encontrados nos mais diversos organismos e sua atividade é altamente regulada pelos seus hospedeiros, uma vez que no processo de transposição, efeitos deletérios decorrentes da inserção/inativação de genes podem resultar em eventos drásticos para o organismo. Foram descritos dois mecanismos de controle desses elementos. O primeiro consiste na inativação da transcrição do elemento (inibição transcricional), e o segundo consiste na degradação do mRNA pelo sistema de interferência de RNA (Inibição pós-transcricional).

Apesar de serem regulados negativamente, foi verificado em plantas de fumo a indução da expressão do retrotransposon Tnt1 em situações de estresse como em injúrias e processo de regeneração. De forma geral a ativação destes é bastante intrigante e durante diversos anos estes elementos foram considerados "DNA lixo" ou "DNA egoísta".

O presente trabalho procurou avaliar a função destes elementos na regeneração de plantas de fumo através de sua inibição nessa fase. A inibição foi realizada através de construções que induzem o sistema de inteferência de RNA, clivando o mRNA dos elementos provindos de qualquer cópia no genoma. Foram selecionados indivíduos geneticamente modificados que apresentaram deficiência de desenvolvimento, ausência de raízes e resposta de hipersensibilidade. 


\section{VII- ABSTRACT}

Transposable elements are DNA sequences that have the ability of transposition. These elements are divided in two groups according to their transposition mechanism. Those that transpose directly as a DNA molecule are called transposons and those that are dependent on a RNA intermediate are called retrotransposons.

Retrotransposons are found in various organisms and are highly regulated by their hosts. In many cases of transposition, the retroelements may be inserted into other genes, causing deleterious effects and damages to the organism. Two control mechanisms have been described in previous studies. One consists of the element transcription inactivation (transcriptional inhibition), and the second consists of the mRNA degradation by the RNA interference system (post-transcriptional inhibition).

Despite the negative regulation of these elements, the induction of expression of Tnt1 retrotransposon was described in tobacco plants under stress situations such as injuries and regeneration. The function of the retroelements, in general, is not yet known although they are usually considered as "junk DNA" or "selfish genes". Therefore, studies on the inactivation of these elements are particularly interesting.

In this work, the function of these elements in tobacco plants was studied by the use of RNAi methods and analysis during the regeneration phase and plant development were evaluated. Phenotypes are described which are related to previous expression studies supporting a specific role for these elements not yet described. 


\section{VI - RERÊNCIAS BIBLIOGRÁFICAS}

Benedito V A, Visser P B, Angenent G C, Krens F A: The potential of virus-induced gene silencing for speeding up functional characterization of plant genes. Genet. Mol. Res. 3 (3): 323-341, 2004.

Bennetzen J L: Transposable elements, gene creation and genome rearrangement in flowering plants. Curr Opin Genet Dev. Dec;15(6):621-7, 2005.

Brasileiro A C M, Carneiro V T C: Manual de transformação genética de plantas. Serviço de produção de informação-SPI, 1998.

Boeke J D: The unusual phylogenetic distribution of retrotransposons: a hypotesis. Genome Res. Sep;13(9):1975-83, 2003.

Brodersen $\mathrm{P}$, Voinnet $\mathrm{O}$ : The diversity of RNA silencing pathways in plants. TRENDS in genetics vol 2 No 5:268-280, 2006.

Buchanan B B, Gruissem W, Jones R L: Biochemistry and Molecular Biology of Plants. Waldorf: Am. Soc. Plant Physiol. 1367p., 2000.

Chaparro C, Guyot R, Zuccolo A, Pie'gu B, Panaud O: RetrOryza: a database of the rice LTR-retrotransposons. Nucleic Acids Research. Vol. 35:D66-D70, 2007.

Clegg M T, Durbin M L: Flower color variation: A model for the experimental study of evolution. PNAS vol.97 No 13: 7016-23, 2000.

Costa AP, Scortecci KC, Hashimoto RY, Araujo PG, Grandbastien MA, Van Sluys MA: Retrolycl-1, a member of the tntl retrotransposon super-family in the Lycopersicon peruvianum genome. Genetica. 107(1-3):65-72, 1999.

Courtial B, Feuerbach F, Eberhard S, Rohmer L, Chiapello H, Camilleri C, Lucas $\mathrm{H}$ : Tnt1 transposition events are induced by in vitro transformation of 
Arabidopsis thaliana, and transposed copies integrated into genes. Mol Genet Genomics 265:32-42, 2001.

Dykxhoorn DM, Novina CD, Sharp PA: Killing the messenger: short RNAs that silence gene expression. Nat Rev Mol Cell Biol. Jun;4(6):457-67. Review, 2003

Ehrenfeld N, Canon P, Stange C, Medina C, Arce-Johnson P: Tobamovirus coat protein $\mathrm{CPCg}$ induces an HR-like response in sensitive tobacco plants. Mol Cells. Jun 30;19(3):418-27, 2005.

Feschotte C, Jiang N, R.Wessler S R: Plant transposable elements: where genetics meets genomics. Nature Reviews. Volume 3:329-41, 2002.

Flavell A J, Smith D B, Kumar A: Extreme heterogeneity of Ty1-copia group retrotransposons in plants. Mol. Gen. Genet. 231:233-242, 1992.

Flavell A J: Retroelements, reverse transcriptase and evolution. Comp Biochem Physiol B Biochem Mol Biol. 1995 Jan;110(1):3-15.

Fritz JH, Girardin SE, Philpott DJ: Innate immune defense through RNA interference. Sci STKE. Jun 13;2006(339):pe27. Review, 2006.

Gaut B S, d'Ennequin M T, Peek A S, Sawkins M C. Maize as a model for the evolution of plant nuclear genomes. PNAS. 97;7008-7015, 2000.

Grandbastien MA, Spielmann A, Caboche M: Tnt1 a mobile retrovirallike element of tobacco isolated by plant cell genetics. Nature 337: $376-380$, 1989.

Grandbastien MA, Audeon C, Bonnivard E, Casacuberta JM, Chalhoub B, Costa AP, Le QH, Melayah D, Petit M, Poncet C, Tam SM, Van Sluys MA, Mhiri C: Stress activation and genomic impact of Tnt1 retrotransposons in Solanaceae. Cytogenet Genome Res. 110(1-4):229-41, 2005. 
Greenberg J T, Yao N: The role and regulation of programmed cell death in plant-pathogen interactions. Cellular Microbiology. (3), 201-211, 2004.

Grishok A: RNAi mechanisms in Caenorhabditis elegans. FEBS Lett. Oct 31;579(26):5932-9, 2005.

Haas BJ, Wortman JR, Ronning CM, Hannick LI, Smith RK Jr, Maiti R, Chan AP, Yu C, Farzad M, Wu D, White O, Town CD: Complete reannotation of the Arabidopsis genome: methods, tools, protocols and the final release. BMC Biol. Mar 22;3:7, 2005.

Hamilton A, Olivier Voinnet, Chappell L, Baulcombe D: Two classes of short interfering RNA in RNA silencing. The EMBO journal. Vol.21 No.17 pp.4671-4679, 2002.

Hanahan D. Studies on transformation of Escherichia coli with plasmids. J Mol Biol. Jun 5;166(4):557-80, 1983.

Hannon G J: RNA interference. Nature. Jul 11;418(6894):244-51. Review, 2002.

Hirochika, $\mathrm{H}$ : Activation of tobacco retrotransposon during tissue culture. The EMBO Journal 12 vol 6:2521-2528, 1993.

Hirochika $\mathrm{H}$, Okamoto $\mathrm{H}$, Kakutani T: Silencing of retrotransposons in arabidopsis and reactivation by the ddm1 mutation. Plant Cell. Mar;12(3):35769, 2000.

Kachroo P, Chandra-Shekara AC, Klessig DF: Plant signal transduction and defense against viral pathogens. Adv Virus Res.;66:161-91, 2006.

Komatsu M, Shimamoto K, Kyozuka J: Two-step regulation and continuous retrotransposition of the rice LINE-type retrotransposon Karma. Plant Cell. Aug;15(8):1934-44, 2003 
Kumar A, Bennetzen J L: Plant retrotransposons. Annu. Rev. Genet. 33: 479-532, 1999.

Lam, E: Controlled cell death, plant survival and development. Nat Rev Mol Cell Biol. Apr;5(4):305-15, 2004.

Leprince A-S, Grandbastien M-A, Meyer C: Retrotransposons of the Tnt1B family are mobile in Nicotiana plumbaginifolia and can induce alternative splicing of the host gene upon insertion. Plant Molecular Biology 47: 533-541, 2001.

Lindbo J A, Dougherty W G: Plant pathology and RNAi: a brief history. Annu Rev Phytopathol. 43:191-204, 2005.

Liu Y, Schiff M, Czymmek K, Talloczy Z, Levine B, Dinesh-Kumar SP: Autophagy regulates programmed cell death during the plant innate immune response. Cell. May 20;121(4):567-77, 2005.

Mallory AC, Vaucheret $\mathrm{H}$ : Functions of microRNAs and related small RNAs in plants. Nat Genet. Jun;38 Suppl:S31-6, 2006

Manetti ME, Rossi M, Costa AP, Clausen AM, Van Sluys MA: Radiation of the Tnt1 retrotransposon superfamily in three Solanaceae genera. BMC Evol Biol. Mar 7;7:34, 2007.

Marillonnet S, Wessler S R: Retrotransposon insertion into the maize waxy gene results in tissue-specific RNA processing. The Plant Cell vol 9, 967-978, 1997.

Mathieu O, Bender J: RNA-directed DNA methylation. J Cell Sci. Oct 1;117(Pt 21):4881-8, 2004.

Melayah D, Binnivard E, Chalhoub B, Audeon C, Grandbastien M A: The mobility of the tobacco Tnt1 retrotransposon correlates with its transcriptional activation by fungal factors. Plant J. Oct;28(2):159-68, 2001. 
Mhiri C, Morel J-B, Audeon C, Ferault M, Grandbastien M-A, Lucas H: Regulation of expression of the tobacco Tnt1 retrotransposon in heterologous species following pathogen-related stresses. The Plant Journal 9(3) 409-419, 1996.

Mhiri C, Morel J-B, Vernhettes S, Casacuberta J M, Lucas, H, Grandbastien M-A: The promoter of the tobacco Tnt1 retrotransposon is induced by wounding and by abiotic stress. Plant Molecular Biology 33: 257266, 1997.

Mittler R, Rizhsky L: Transgene-induced lesion mimic. Plant Mol Biol. Oct;44(3):335-44, 2000.

Miura A, Yonebayashi S, Watanabe K, Toyama T, Shimada H, Kakutani T: Mobilization of transposons by a mutation abolishing full DNA methylation in Arabdopsis. Nature Vol. 411 212-214, 2001

Monteiro-Vitorello, Oliveira M C, Zerillo M M, Varani A M, Civerolo E, Van Sluys M A: Xylella and Xanthomonas Mobil'omics. OMICS A Journal of Integrative Biology

Volume 9, Number 2, 2005

Murashige T, Skoog F: A revised medium for rapid growth and bio assays with tobacco tissue cultures. Phisiol. Plant, v.15, p.473-97, 1962.

Robert VJ, Vastenhouw NL, Plasterk RH: RNA interference, transposon silencing, and cosuppression in the Caenorhabditis elegans germ line: similarities and differences. Cold Spring Harb Symp Quant Biol. 69:397402, 2004.

Sabot F, Schulman A H: Parasitism and the retrotransposon life cycle in plants: a hitchhiker's guide to the genome. Heredity. Dec;97(6):381-8, 2006. 
Scortecci K C, Dessaux Y, Petit A, Van Sluys M A. Somatic excision of the Ac transposable element in transgenic Arabidopsis thaliana after 5azacytidine treatment. Plant Cell Physiol. 38(3): 336-343, 1997.

Stuwart-Rogers C, Flavell A J: The evolution of Ty1-copia group retrotransposons in gymnosperms. Mol. Biol. Evol. 18(2):155-163. 2001

Takeda S, Sugimoto K, Otsuki H, Hirochika H: Transcriptional activation of the tobacco retrotransposon Tto1 by wounding and methyl jasmonate. Plant Mol Biol. 36(3):365-76, 1998.

Takeda S, Sugimoto K, Kakutani T, Hirochika H: Linear DNA intermediates of the Tto1 retrotransposon in Gag particles accumulated in stressed tobacco and Arabdopsis thaliana. The Plant Journal, 28(3), 307-317, 2001.

Waterhouse P M, Wang M B, Lough T: Gene silencing as an adaptive defence against viruses. Nature. Jun 14;411(6839):834-42. Review, 2001.

Wesley S V, Helliwell C A, Smith N A, Wang M, Rouse D T, Liu Q, Gooding P S, Singh S P, Abbott D, Stoutjesdijk P A, Robinson S P, Gleave A P, Green A G, Waterhouse P M: Construct design for efficient effective and high throughput gene silencing in plants. The Plant Journal 27(6), 581-590, 2001.

Vaucheret $\mathrm{H}$ : Post-transcriptional small RNA pathways in plants: mechanisms and regulations. Genes Dev. Apr 1;20(7):759-71. Review, 2006.

Voinnet O: RNA silencing as a plant immune system against viruses. TRENDS in genetics. August Vol.17. No.8:449-59, 2001. 